\title{
Categorical Stigma and Firm Disengagement: Nuclear Power Generation in the United States, 1970-2000
}

\author{
Alessandro Piazza ${ }^{1, *}$ \\ Fabrizio Perretti ${ }^{2}$
}

Organization Science, 2015, 26(3): 724-742

We are grateful to those who provided us with valuable feedback during the development phase of this paper, and particularly to Fabrizio Castellucci, Ivana Katic, John Paul MacDuffie, Renate Meyer, Rhonda Reger, David Ross, and Carlo Salvato, as well as to Senior Editor Brayden King and three anonymous reviewers. Shuye Lu provided able research assistance, while Patrizio C. Camprini helped fill the gaps in our knowledge of the empirical setting. The first author acknowledges support from Bocconi University and Columbia Business School, while the second author would like to thank CRIOS-Bocconi for supporting this research. Errors remain our own.

Keywords: stigma; nuclear power; identity, categories; firm behavior

${ }^{1}$ : Columbia Business School, Management Division, Uris Hall, 3022 Broadway, 10027 New York, NY.

2: Bocconi University, Department of Management and Technology, Via Roentgen 1, 20136 Milan, Italy.

*: Corresponding author. Email: apiazza3195@,columbia.edu 
Since the very onset of organization theory as a discipline, scholars have acknowledged that the environment in which many organizations operate is socially complex. Aside from obtaining the material resources they need to perform their functions, for many organizations gaining acceptance into their environment is just as critical for survival (Ruef and Scott 1998). Institutional arguments hold that organizational legitimacy (Suchman 1995, Tost 2011) is typically achieved either through adherence to cultural norms, symbols, and beliefs that are typical of the field (Meyer and Rowan 1977) or by conforming to audiences' expectations (Ruef and Patterson 2009, Zuckerman 1999). Yet, when organizations engage in activities that are morally questionable or socially contested, gaining and maintaining legitimacy might prove problematic. As a result, acts of organizational misconduct (Greve et al. 2010), such as financial (Jonsson et al. 2009) and environmental (Hoffman and Ocasio 2001) scandals frequently result in legitimacy loss. This is even more of an issue for organizations whose very existence requires them to routinely engage in contentious practices (Hudson 2008), however, because such organizations might find legitimacy hard to achieve in the first place. Examples of such organizations include tobacco companies, arms producers (Vergne 2012), HIV/AIDS treatment advocacy groups (Maguire et al. 2004), men's bathhouses (Hudson and Okhuysen 2009), and even organizations involved in the commerce of cadavers for medical research (Anteby 2010). These organizations are typically condemned by stakeholders because of their open involvement in one or more activities that the audiences find morally objectionable. The idea that entire groups of organizations can be categorized as similar and become a target for disapproval due to their continued engagement in contentious practices has been referred to as categorical stigma in the literature (Vergne 2012).

Stigma has long been acknowledged as harmful for individuals and organizations (Goffman 1963, Hudson and Okhuysen 2014), resulting in social and economic sanctions (Sutton and Callahan 1987) as well as disidentification from stakeholders (Elsbach and Bhattacharya 2001); as a result, social actors try to put strategies in place in order to limit the amount of disapproval they receive. While the management of stakeholder disapproval has long since been recognized as highly consequential (Elsbach and Sutton 1992, Elsbach 1994), attracting a large amount of scholarly attention in the process, to this day extant research on organizational responses to stigma has mainly focused on the role of coping strategies such as defensive practice adoption or 
impression management techniques (Carberry and King 2012, Desai 2011, McDonnell and King 2013). Such strategies, however, are largely cosmetic in nature, since their goal is to influence how audiences perceive the organization, without altering the underlying pattern of activities that caused disapproval to emerge in the first place. In this respect, a far more radical and transformative way to address disapproval would consist in reducing the extent of the organization's involvement in stigmatized activities. By disengaging from a category that is under duress, organizations can potentially address stigma at its source. Yet this is not always a feasible course of action: for undiversified organizations whose core activities are targeted (Hudson and Okhuysen 2009) reducing the level of exposure to a stigmatized category would be substantially equivalent to exiting the field. Furthermore, even organizations that have the option of disengaging in favor of less controversial activities might choose not to do so for a variety of reasons, including switching costs (Selznick 1949), escalation of commitment (Ross and Staw 1993, Staw 1976), path dependence (Vergne and Durand 2010), inertia (Hannan and Freeman 1984), and identity concerns (Phillips et al. 2013, Zuckerman et al. 2003). In spite of all the above mechanisms holding them in place, however, organizations occasionally do produce such an extreme response. In this paper, therefore, we investigate the determinants of this choice. In other words, we ask: how will an organization respond to the stigmatization of a category to which it belongs? More specifically: what determines whether the organization will reduce its engagement in the category, instead of coping with stigma in other ways?

In the remainder of this paper, we build a theoretical framework to address this puzzle. Building on the categorization literature, we first conceptualize groups of organizations engaging in contentious practices as stigmatized categories in the eyes of the audience. Treating disengagement from a stigmatized category as an extreme response aimed at reducing disapproval, we then propose that an organization's reaction to categorical stigma will be a function of the intensity of disapproval targeting the category, the exposure of the stigmatized category in the media, and the focal organization's level of membership in the category. Below, we briefly discuss past work on categories, stigma and organizational identity, which we use to ground our theory and hypotheses. We then illustrate the details of our study of nuclear power generation in the United States between 1970 and 2000, which relies on a dataset of proposed new nuclear reactors and provides support for our hypotheses; in so 
doing, we also explain the variables and methods we used in our analysis. Following this, we report our results and several robustness checks before elaborating the implications of our findings in our conclusion.

\section{THEORY AND HYPOTHESES}

Conceptualizing categorical stigma. In organizational theory, the study of stigma stems directly from

Goffman's (1963) seminal work in sociology. Stigmatization occurs when an individual possesses (or is believed to possess) some attribute or characteristic that conveys a devalued social identity within a particular context (Crocker et al. 1998). Stigmatizing marks may be linked to three different types of stigma (Goffman 1963; Major and O’Brien 2005): appearance (e.g., physical deformities), behavior (e.g., drug addiction), or group membership (e.g., African Americans). Even though the notion of stigma originally applied to individuals, it was later brought to bear on the study of organizations, which—as social actors — can also be targets for stigmatizing judgments. Devers et al. (2009: 155) define organizational stigma as a "label that evokes a collective perception that the organization is deeply flawed or discredited", highlighting the essence of stigma as a negative judgment rooted in labeling and social control.

Scholars have also acknowledged that stigma can arise because of manifold reasons and, as a result, multiple types of stigma can be identified. Similarly to individuals, organizations may be stigmatized because of their appearances, for example in the case of the illegitimacy suffered by the firms named "dot-com" after the bursting of the Internet bubble (Glynn and Marquis 2004); behavior, such as in the case of organizational misconduct (Greve et al. 2010), or group membership, for instance the case of the arms industry (Vergne 2012). Our work will focus on the third type of stigma, which Goffman (1963: 4) originally defined as tribal stigma because "it equally contaminates all members of a family". By bridging stigma with the well-established literature on categorization processes in organizational theory (see Negro, Kocak, \& Hsu, 2010 for a review) we conceptualize stigma as a macro, field-level phenomenon affecting all organizations that are members of a category, simply due to being associated with it. 
Briefly, categories are cognitive structures (Rosch 1978) that allow audiences to make sense of organizations by making them fit into a classification system. By drawing boundaries between what is expected of an organization and what is not, categorical schemas shape the social identity of organizations in the eyes of audiences (Hsu and Elsbach 2013). A category can thus be any set of organizations structured around common elements such as being part of the same industry (Porac et al. 1999), offering similar products (Kennedy 2005, Lounsbury and Rao 2004), engaging in similar activities (Alexy and George 2013), and so forth. After Vergne (2012: 1030), we thus conceptualize stigmatized categories as "groups of organizations, such as arms or tobacco producers, whose liability prompts out-group members to keep their distance to avoid a potentially harmful association". In this light, stigma arises due to audience disapproval of a specific organizational category, so that the entire family of organizations possessing these undesirable attributes will be collectively stigmatized.

Categorical stigma can thus be defined as a negative evaluation arising from a social actor's association with a group that is recognized as engaging in contested practices. Differently from other types of organizational-level stigma (see Hudson 2008), categorical stigma does not target any individual organization in particular; rather, it applies to entire groups of organizations that are cognitively assimilated by virtue of their membership and it affects organizations vicariously as members of the category.

Theorizing organizational decisions in response to categorical stigma. After having defined what we mean by categorical stigma, we move on to the key theoretical puzzle motivating this paper, i.e. the behavior of organizations that are subjected to it. The sociological literature has shown that stigmatized individuals cope with stigma in a variety of ways. In Goffman's work (1963), for example, stigmatized persons often emerge not as powerless victims, but as strategists and con artists (Anspach 1979). Examples of such strategies, which include amongst others "passing” and "covering” (Goffman 1963), "concealment" and "withdrawal” (Jones et al. 1984) "retreatism" and "disassociation" (Anspach 1979), can be characterized as engagement versus disengagement strategies (Major and O’Brien 2005). Similarly, the organizational literature has identified a variety of ways in which organizations attempt to cope with disapproval from stakeholders, such as impression management (McDonnell and King 2013) and symbolic practice adoption (Westphal and Zajac 1994, 1998). These techniques are generally enacted to restore the organization's legitimacy (Pfarrer et al. 2008) repair its 
reputation (Rhee and Valdez 2009), and ensure survival (Hudson and Okhuysen 2009). More recently, scholars have also begun to tackle the question of what determines how organizations will react to disapproval. For instance, Desai (2011), in a study of the U.S. railroad industry, investigated how firms responded to threats to the legitimacy of their field due to traumatic events (i.e. railroad accidents), finding that firms are more likely to engage in defensive institutional work (Lawrence et al. 2011) when they receive higher scrutiny of related issues or when their similarity with the accident-stricken organization is low. Carberry \& King (2012) examined the adoption of a controversial accounting practice by firms following the Enron scandal: organizations facing federal investigations for corporate fraud or shareholder activism were found to be more likely to adopt the new practice, as were organizations that received higher levels of media exposure.

All of the above are examples of proactive, defensive responses which organizations put in place in an attempt to restore their public image (McDonnell and King 2013, Zavyalova et al. 2012). On the other hand, similarly to stigmatized persons, organizations have also a different kind of option at their disposal to limit disapproval from stakeholders: more specifically, they have the option of disengaging from the stigmatized activities, by reducing or withdrawing their involvement in them. In the case of diversified firms, for instance, stigma management can be accomplished either by diluting audience's attention through multiple category straddling (Vergne 2012) or by divesting their assets in stigmatized areas of activity (Durand and Vergne in-press). The circumstances under which organizations might opt to disengage vis-à-vis adopt symbolic responses to stigma have not been thoroughly investigated. Therefore we ask: when a category to which the organization belongs becomes a target for stigma, what determines whether the organization will choose to disengage from it?

Stigma intensity. Our first, baseline hypothesis concerns whether the intensity of stakeholder disapproval targeting a category—which we label stigma intensity—will have an impact on the behavior of organizations affiliated with the category. Extant studies have recognized that stigma can vary in magnitude: Hudson (2008) discussed the degree or strength of stigma, while Hudson and Okhuysen (2009) indicated that the intensity of stigma can be markedly different across settings. Here, we argue that since disapproval can vary from quiet disapprobation to vocal condemnation, involving anything from a few isolated social actors to the plurality of an audience, the intensity of categorical stigma is likely to have a bearing on organizations' likelihood 
to disengage from the category. In particular, we would expect more intense stigma to result in stronger pressures on organizations to disengage, other things being equal. Thus:

Hypothesis 1. The greater the intensity of stigma experienced by a category, the higher the likelihood that organizations will disengage from it.

The role of the media and audience attention. Our second proposed contribution to the literature concerns the role of audience attention in stigmatization. Stigma refers to an attribute that is deeply discrediting because of its deviance from social norms and legitimate social categories (Goffman, 1963). According to a loosely defined group of theorists whom Matza (1969) refers to as "the neo-Chicagoans" - such people as Edwin Lemert, Howard S. Becker, and Erving Goffman - and to the labeling theory they introduced, deviance is not a property inherent in certain attributes or forms of behavior; rather, it is a property conferred upon these forms by the audiences, which directly or indirectly witness them. As described by Malinowski's observations of Trobriand islanders, no organized social action is taken with respect to a behavior that is considered deviant from social norm, unless there is public announcement of the deviation (Malinowski 1926). From this sociological perspective, the critical variable in the study of deviance is the social audience, which eventually decides whether or not any given action or attributes will become a visible case of deviation (Erikson 1961).

In a mass society, this function of public exposure is institutionalized in the mass media of communication. Press, journals, radio and television have been peculiarly modern devices for bringing a public space into existence (Lazarsfeld and Merton 1948). In media-saturated societies, such devices not only are "a site on which various social groups, institutions, and ideologies struggle over the definition and construction of social reality" (Gurevitch and Levy 1985 : 19), but mass media discourse also dominates public opinion, both reflecting it and contributing to its creation (Gamson 1988). The power of the mass media on public opinion has been recognized since the Second World War, when mass communication entrenched itself as a field in its own right. To quote one of its founding fathers, "some kinds of communication on some kinds of issues, brought to the 
attention of some kinds of people under certain kinds of conditions have some kinds of effects" (Berelson 1948 : 172)

It was with the agenda-setting theory (McCombs and Shaw 1972) - the successful transfer of salience from the media agenda to the public opinion - that such effects were better described and measured. The basic agenda-setting effect involves the impact of exposure to information about an issue in the media on the salience of that issue within the audience. The mass media force attention to certain issues, "constantly presenting objects suggesting what individuals in the mass should think about, know about, have feelings about" (Lang and Lang 1966 : 468). The audience will regard as more important the news items that are covered frequently and prominently. Higher levels of coverage will thus be associated with higher issue salience. Based on the issueattention cycle (Downs 1972 : 39), according to which the public perception of domestic issues seems to pass through a cycle of "heightening public interest and then increasing boredom with major issues", several studies on the tradition of agenda-setting research noted that the agenda-setting effect might dissipate over time (Watt and Van den Berg 1981, Watt et al. 1993, Weaver et al. 1981, Zucker 1978).

From a cognitive perspective, the drop-off in public attention has been explained by the limits of a wide variety of sensory processes, including memory, selective attention and habituation. Research on memory - since Ebbinghaus (1913) - has generally indicated that memory decays exponentially, with most information forgotten soon after exposure (see Woodworth and Schlosberg 1954). However, the decreasing salience of issues is also generally linked to the limits of the public's resources, both in terms of selectivity and psychological capacity (Pashler 1999), and to the audience adaptation or habituation to a repeated stimulus (Berlyne 1951). Not only the resource of attention among the public is a very scarce one, with a tendency to shift attention to stimuli that are novel or unexpected, but - like many other organisms - people also decrease or cease to respond to a stimulus after repeated presentations (e.g. Mitchell 2014).

Based on such basic cognitive processes it is possible to explain the empirical results of several studies where agenda-setting declines progressively over the life of an issue as the news audience accumulates information about the topic. In terms of our argument, this means that stigmatized issues are subject to the same decay process and that, for a given level of stigma intensity, issues that have received much coverage should 
show less salience in the public opinion. Organizations that have been able to resist the initial wave of stigmatization will then be less exposed to scrutiny of the public opinion. Hence:

Hypothesis 2. The effect of stigma intensity on the likelihood of disengagement is moderated by media exposure, so that the posited relationship will be weaker when media coverage is high.

Extent of categorical membership and identity. Our third—and final—proposed contribution concerns the extent of membership in a stigmatized category as a possible antecedent of organizational responses to stigma. Many modern organizations are not specialized, in the sense that they often engage in a large variety of activities. Since categories are based on shared understandings of what social actors are expected to do, and since generalist organizations typically span these taken-for-granted boundaries, audiences might perceive that such organizations hold partial memberships in multiple categories (Hannan 2010, Hsu et al. 2009). As a result, organizations that engage in a variety of different activities might be perceived by their audience as belonging to several different categories, some of which are likely unproblematic while others might be socially contested. This is the case of Vergne's (2012) study of defense sector, in which firms like Boeing are seen as engaging in both legitimate activities (building civilian aircraft) and stigmatized ones (arms production). In general terms, whether spanning multiple categories is beneficial or harmful for organizations has been the object of a lively debate among scholars (Alexy and George 2013, Hannan 2010, Hsu 2006, Vergne 2012). For our purposes, however, it is worth noting that organizations whose involvement in a stigmatized category represents a significant portion of their activities are more likely to see the stigmatized category as a "central, enduring and distinctive" part of their identity (Gioia et al. 2013, Whetten 2006), even if the category is stigmatized by stakeholders. That of identity (“who we are as an organization”) is a key idea in organization studies (Gioia et al. 2013) and the argument that identity concerns might drive -at least in part- this kind of choices is not new in the literature: Phillips et al. (2013) in a study of corporate law firms in Silicon Valley recently found that identity acts as a barrier to diversification, as corporate law firms were willing to diversify into low-status areas such as family law but not into other areas, such as personal injury law, because of identity constraints and potential backlash 
from customers. In a similar fashion, we argue that identity-based dynamics are at play when it comes to choosing whether to disengage from a stigmatized category: if the involvement in a certain category, however stigmatized, is considered "core" and integral to the purpose of the organization, it stands to reason that the organization will be less likely to disengage from it and more likely to tackle stigma by other means, such as impression management (McDonnell and King 2013) or symbolic practice adoption (Carberry and King 2012). Conversely, when membership in a stigmatized category is marginal organizations will be less likely to perceive stigma as a threat to their identity (Elsbach and Kramer 1996); disengagement then becomes a much more viable option to limit the social and economic sanctions deriving from stigmatization. Thus:

Hypothesis 3. The greater the extent of an organization's membership in a stigmatized category, the lower the likelihood that the organization will disengage from it.

\section{NUCLEAR POWER GENERATION IN THE UNITED STATES}

We propose to test the foregoing considerations in the context of nuclear power generation in the United States, a practice whose legitimacy was challenged in the final quarter of the $20^{\text {th }}$ century, first by environmental activists and then by the general public. After a succinct introduction to the industry, we conceptualize nuclear power as a stigmatized category and we elaborate on how stigmatization was reflected in the media.

\section{Industry background.}

Nuclear power generation involves the use of nuclear reactions to generate electricity and heat. While most conventional power stations_-such as oil-fired, coal-fired or gas-fired ones—rely on combustion processes to generate electricity, nuclear power is grounded in scientific discoveries which occurred in the $20^{\text {th }}$ century, mostly in the field of physics.

The first man-made nuclear reactor was assembled in 1942 at the University of Chicago, under the supervision of Italian physicist Enrico Fermi. This was part of a larger research and development project known as the Manhattan Project, whose aim was to create weapons based on nuclear fission technology to be employed during 
and after World War II; notably, the project produced the two nuclear devices detonated in Hiroshima and Nagasaki, Japan, in 1945. The project also resulted in the establishment of several national research laboratories, now overseen by the U.S. Department of Energy (DOE); one of them, the Argonne National Laboratory, was assigned the lead role in developing commercial nuclear energy technology. In fact, by the early 1950s, the high costs of developing nuclear technology for military purposes had pushed scientists and government officials to find civilian uses for it, in order to justify the government's sizeable expenditures. This led to the passing of the Atomic Energy Act of 1954, which encouraged private entities to build nuclear power facilities and allowed companies to gain access to restricted government information about nuclear energy production and the production of fissile materials. The first commercial nuclear power plant, Shippingport, was opened by President Eisenhower in 1958. Electric utilities readily embraced the new technology, and many other plants followed: in 1970, 20 utilities were already operating 20 plantseach with one or more units - in 11 states, but by 1980 these numbers had grown to 42 utilities operating 52 plants in 27 states. Optimism ran rampant in the early days of nuclear power, with the atom being touted as a safe, affordable, and sustainable energy source for the future, which led some—-such as U.S. Navy Admiral Lewis Strauss, Chairman of the Atomic Energy Commission, in what is now an infamous quote - to state that nuclear power would eventually result in "electrical energy too cheap to meter".

Things took a rather different turn in the 1970s, however. In his 2009 book Our Choice, former U.S. VicePresident and current environmentalist opinion leader Al Gore observed that "of the 253 nuclear power reactors originally ordered in the United States from 1953 to 2008, 48 percent were canceled, 11 percent were prematurely shut down, 14 percent experienced at least a one-year-or-more outage, and 27 percent are operating without having a year-plus outage". Figures 1 and 2 provide a visual overview of the temporal evolution of nuclear reactors in the United States between 1970 and 2000.

[Figure 1 - Nuclear power units ordered, connected, shut down and cancelled in the U.S. by year]

[Figure 2 - Cumulative number of nuclear units in the U.S. by stage of development, by year] 
These trends warrant a few considerations. On purely technical and economic grounds, that about half of the proposed nuclear reactors—i.e., reactors for which the Nuclear Regulatory Commission (NRC) granted approval— were never completed is quite remarkable, and such a high rate of project cancellations is all the more surprising for a variety of reasons. First of all, in the vast majority of occurrences they were proposed by utility companies with extensive experience in producing electricity, and in some cases even operating existing nuclear reactors. Secondly, before the U.S. electricity market was deregulated, starting in the late Nineties, utility companies produced, distributed and sold energy in a regime of substantial monopoly (Hirsh 1999); the electric power industry, therefore, was not particularly subject to competitive pressures. Third, once nuclear units start operating they are very rarely shut down, unless they reach the end of life or they encounter serious technical difficulties. As a result, while the total number of nuclear reactors in operation has been growing for decades—-largely because of their reliability and long lifespan—the decline of nuclear as an electricity source is most evident when one looks at the orders for new nuclear units, which have been stagnant for years. Traditional explanations for this phenomenon include slower rate of growth in electricity demand, significant cost and time overruns, more complex regulatory requirements, the nuclear accident at Three Mile Island, and the 1973 oil crisis. Most of these arguments, however, apply to all nuclear reactors that had not been completed at a given point in time, and they are thus largely unable to explain their variance in outcomes. For instance, many argue that the Three Mile Island accident in 1979 spurred a wave of cancellations which substantially marked the end of the nuclear industry. Yet, in the ten years immediately following the accident (1980-1989), only 39 reactors were cancelled, while 67 were completed. The same line of reasoning applies to the 1973 oil crisis, which lowered energy demand growth forecasts for the following decades and indirectly stymied the development of the nuclear industry: between 1974 and 1977 only 22 units were cancelled, while 30 were completed. These trends suggest that, while economic, technical, or political arguments might be adequate to justify the downturn of nuclear power generation at the sector level, they fall short when it comes to explaining individual outcomes. To understand what drove individual utilities to complete their nuclear units while other utilities were cancelling them, we bring in the theoretical framework outlined in the previous section and, more specifically, we look th the stigmatization of nuclear power (Horlick-Jones et al. 2012) first by environmental activists and then by the general public.

\section{Nuclear power as a stigmatized category.}


In a way, nuclear power generation and the anti-nuclear movement have evolved in parallel: since nuclear fission was originally developed for military applications, testing of nuclear weapons became a major topic of discussion already in the Forties and Fifties. Nuclear military technology stirred controversy and sparked debate, eventually leading to the formation of associations of concerned citizens and, later, to the conferral of the Nobel Peace Prize to Linus Pauling for his opposition to nuclear device testing in 1962. Eventually, above-ground tests were stopped in 1962 and replaced with underground testing. A few years later, however, the opposition to nuclear weapons testing gradually morphed into opposition to nuclear power. Pacific Gas \& Electric, the first electric utility that attempted to build a commercially viable nuclear power plant in the United States at Bodega Bay, faced considerable opposition by local citizens starting in 1958, garnering the support of the Sierra Club, among others. Plans for construction at Bodega Bay power plant were eventually abandoned in 1964. Today, historians trace the birth of the anti-nuclear movement in the United States to this episode (Wellock 1998). During the following decades, hundreds of sit-ins and marches took place all over the country to protest the construction and operation of nuclear power plants. Protests reached a peak in the 1970s, and previously isolated anti-nuclear activists managed to form a national coalition including prominent environmentalist groups such as the Sierra Club, Friends of the Earth, Natural Resources Defense Council, Union of Concerned Scientists, and Critical Mass. The level of activism increased dramatically, pushing for initiatives to control or halt the growth of nuclear power, often by introducing more complex safety requirements. This widespread popular ferment kept the issue before the public and contributed to growing public skepticism about nuclear power. Even before the accident at the Three Mile Island Nuclear Power Plant in Pennsylvania took place on March 28, 1979, anti-nuclear activists had gained the support of prominent experts, moving beyond local protests and politics to gain a wider appeal and influence, as well as a great deal of national attention (Walker 2006). Reinforced by the more recent accidents at Chernobyl, USSR (1986) and Fukushima, Japan (2011), the stigma surrounding everything nuclear persists to this day. In an illuminating study, Horlick-Jones et al. (2012) investigate the degree of stigma associated with nuclear energy technologies by having laypersons discuss a related issue, fusion power. Their results show that the nuclear label is able to generate a sense of stigma even for technologies previously unknown to the general public, such as nuclear fusion. What is even more relevant for the purposes of our study is that "group participants displayed an orientation towards the cultural norm of nuclear stigma, 
whilst tending to argue, in pragmatic ways, for the benefits of nuclear power technologies" (Horlick-Jones et al., 2012 : 528-529). This suggests that perhaps the role of the media in shaping processes of stigmatization is more prominent than previously envisioned. If this is the case, adding the last piece to our empirical puzzle will thus require us to delve more deeply into the role played by the media in the social construction of the stigma surrounding nuclear power (Gamson and Modigliani 1989).

\section{DATA AND METHODS}

In the empirical section of this paper, we take an ecological approach to the problem by studying a population of proposed new nuclear reactors which were approved by the Nuclear Regulatory Commission (NRC). We match information on each reactor with data about its electric utility owners and we attempt to explain the variance in outcomes — about half of the units in our sample were completed, while the remainder were cancelled—based on categorical membership and media-based arguments.

Nuclear and conventional power generation data. We assembled our dataset from three main sources: 1) the PRIS (Power Reactor Information System) online database maintained by the International Atomic Energy Agency (IAEA); 2) historical electric generation data collected by the Energy Information Administration (EIA) for each plant operated by electric utility companies through Forms EIA-906, EIA-920 and EIA-923; and 3) the Nuclear Regulatory Commission's (NRC) Agency-wide Documents Access and Management System (ADAMS). By triangulating these sources, we were able to construct our core dataset containing the following information for each proposed new nuclear unit approved by the NRC: unit name, plant name, year of order, year of cancellation/completion, utilities owning shares in the unit, shares owned by each utility, plant location (nearest town and geographic coordinates), county and state.

We then used this information to create a list of all electric utilities which owned shares in a nuclear plant at any point in time, and we looked for information about each of these, particularly to check whether they were bought by other companies or they changed name within our observation window (1970-2000). Each utility was traced back to the highest level of ownership, under the assumption that decision-making capabilities reside at that level (Marquis and Huang 2010, Zollo and Singh 2004); in so doing, we grouped all electric utilities owned 
by same holding company by means of a unique identifier. Finally, for each year in our observation window, we calculated the annual electricity generation in MWh—both by nuclear sources and by other sources_-based on the generation data, grouping together those utilities that were owned by a common holding company ${ }^{1}$. Similarly, for every year between 1970 and 2000, we calculated the number of nuclear and nonnuclear generating units controlled by each utility and holding company. While most units have been typically owned by more than one company, a majority owner can usually be identified; therefore, for units that are owned by more than one utility, we made the assumption that the majority owner would be responsible for taking decisions regarding completion and cancellation of the unit. Accordingly, each proposed unit in our sample was matched with its majority owner and its characteristics. To compensate for the slight oversimplification introduced by this assumption, for each unit in our dataset we included a variable for the number of owners as well as one for whether any of the utilities involved were publicly-owned, which we used as controls.

Our initial sample thus included 253 NRC-approved reactor units, with 133 utilities (public and private) owning shares in them. We then researched each of these units in detail, and proceeded to eliminate from the sample: 1) units whose construction was completed prior to 1970; 2) units whose eventual cancellation was decided not by the relevant electric utilities, but either by state governments or by courts of law. ${ }^{2}$ Since we are interested in firm-level decisions, this latter choice was made to eliminate confounding effects from our data. This left us with 214 units which were cancelled or completed between 1970 and 2000; taken together, they constitute our final sample.

Media coverage of nuclear power. Our main source of textual data was the online repository ProQuest. We proceeded as follows: first, we downloaded from ProQuest all articles published in the New York Times from 1960 to 2000 on the topic of nuclear power by means of appropriately chosen search terms 3 ; doing so yielded about 9000 articles. We then read these articles one by one to make sure that they actually dealt with,

${ }^{1}$ Generation data was not available for years prior to 1970 , a fact which restricted our observation window.

${ }^{2}$ For instance, two units to be built at a site close to Jamesport, NY were rejected by the State of New York in 1980; as such, they are not included in our analysis. In a similar fashion we also excluded the Bailly, Somerset, Sundesert, and Zimmer power plants, among others.

${ }^{3}$ Typically the combination of either atom, nuclear or atomic coupled with one or more of the following: plant, unit, reactor, industry, energy, power. 
or had implications for, domestic civilian nuclear power; this meant excluding articles having to do exclusively with domestic/foreign policy and military technology, such as nuclear weapons. These articles altogether comprised about a third of our sample. We were then left with a selection of about 5700 articles, which were then individually coded as either positive, negative, or neutral based on their content. Table 1 provides details on how the articles were coded, as well as examples of classified articles, while Figure 3 shows the temporal evolution of media coverage of nuclear power in our observation window. All articles were manually coded by the first author, but in order for us to verify the reliability of our media content measure, two additional coders were asked to reclassify a random subsample of 50 articles. Since we wanted to make sure that the classification of articles would be substantially independent of knowledge of nuclear issues, one of the coders was an undergraduate student while the other held a Ph.D. in Nuclear Engineering. The Fleiss' kappa value for the three raters was 0.77, which indicates excellent agreement (Fleiss 1981).

[Figure 3. Coverage of nuclear power generation in the New York Times]

We chose the New York Times for our analysis due to it being arguably one of the most widely circulated national newspapers in the United States covering general topics; moreover, it was the only one whose full text availability on ProQuest spanned our entire observation window (1970-2000). This forced us to rely on a single source for this study, which in turn led us to check whether the data we collected would be reflective of actual trends. For this purpose, we used the same method described above to collect and code articles published in the Wall Street Journal and the Washington Post on the same topic, albeit in a shorter time interval. In both cases, the results substantially mirrored the trends observed in the New York Times in terms of the amount and tenor of media coverage ${ }^{4}$.

\footnotetext{
${ }^{4}$ Following the suggestion of a reviewer, we also repeated our ProQuest search on other outlets such as the LA Times and the Chicago Tribune to check for evidence of geographical bias. Although we did not code the content of these latter articles, the number of articles covering issues related to nuclear power is similar across outlets, suggesting that geographic bias is unlikely to be a major concern.
} 
Miscellaneous data. The power generation data and the textual data described above represent the bulk of our dataset. We did however use Internet sources to code some control variables: the Energy Information Administration (EIA) website for coal and oil spot prices, as well as Wikipedia for data about the political affiliation of governors of each U.S. State in the 1970-2000 observation window of our study. For robustness checks, we also relied on cost data found in Komanoff (1982) and Koomey \& Hultman (2007). Finally, to control for social movement pressure we used a database of protest events collected by researchers at Stanford University as part of the Collective Action Project to create a count variable of protest events that happened in the same state as the proposed new unit. Protest events are defined as any type of activity that involves more than one person and is carried out with the explicit purpose of articulating a claim against (or expressing support for) a target or issue. For a particular protest event to be included in the dataset, the event must have happened in the public sphere or have been open to the public. Thus, private or closed meetings by social movement actors are not included, but events within organizations (e.g., schools, churches, private organizations) are included if they were open to the public. Since antinuclear protests are identified by means of an unique claim code, we were able to create for each proposed nuclear unit in the dataset a simple count variable of all antinuclear protests to have occurred in the same state in the previous 2 years ${ }^{5}$.

\section{Measurement}

Dependent variable. Our hypotheses concern whether electric utility companies will elect to complete a new nuclear reactor unit or, conversely, to abandon the project. Accordingly, our main dependent variable for this study is binary, taking value 1 if the project was ultimately cancelled and 0 if it was completed. Given the general unavailability of data outside of our thirty-year observation window (1970-2000), only nuclear reactor units that were completed or cancelled between 1970 and 2000 are included in our sample. This excludes units whose construction was completed prior to 1970, but it includes reactors approved between 1970 and 1978. No new reactors were approved for construction between 1978 and 2000, and the last units to be cancelled or completed were Perry-2 (in 1994) and Watts Bar-1 (in 1996), respectively.

\footnotetext{
${ }^{5}$ For robustness, we also used moving windows of 1 and 3 years; all three variables were found to perform similarly.
} 
Independent variables. As far as Hypothesis 1 is concerned, the independent variable of interest is stigma intensity. After Devers, Dewett, Mishina, \& Belsito (2009), we argue that stigma is rooted in discredit and disapproval from stakeholders. Since nuclear power is well-known issue with broad societal implications, disapproval is likely to be publicly expressed and reflected in the media. Therefore, we decided that a measure of stigma intensity based on media content would be most appropriate, as well as consistent with similar work being carried out in this area (Deephouse 1996, Jonsson and Buhr 2010, Zavyalova et al. 2012). Using the New York Times articles we collected, for every year in our observation window we modeled stigma intensity as the ratio of negative articles to the total number of articles. For each year in our observation window, we calculated the ratio based on articles published in the previous three years. For robustness, we also ran the study using moving windows of one year; the results were found to be qualitatively similar.

Hypothesis 2 involves media exposure as a moderator of the relationship proposed in Hypothesis 2. After Fombrun \& Shanley (1990), our measure is a simple count variable of articles published on nuclear power within a specified time frame. Like in the case of stigma intensity, we used three-year moving windows, and once again results are found to be largely robust to the choice of time interval used (one or three years). Since media exposure and stigma intensity were found to be highly correlated, we made them orthogonal using a modified Gram-Schmidt orthogonalization procedure implemented through the orthog command in STATA 12, so as to partial out the common variance. Unless otherwise specified, all of the independent variables were lagged by one year.

Lastly, in Hypothesis 3 the main independent variable is the extent of membership in the nuclear power generation category. Following Vergne (2012), we conceptualize membership in a stigmatized category as the relative extent to which an organization engages in activities pertaining to that category. As far as our empirical setting is concerned, nuclear power generation constitutes the stigmatized category, but utility companies have a variety of other options available to them for generating the energy they need to meet local demand, such as coal-fired, oilfired and gas-fired power plants. ${ }^{6}$ Accordingly, we define the extent of membership as the ratio between the

\footnotetext{
${ }^{6}$ Although renewables have played an important role in the U.S. electric power industry since the late $1970 \mathrm{~s}$, they are not prominently featured in our analysis because — until recently_most utility companies did not directly engage in energy production
} 
number of nuclear generating units operated by a utility and the total number of generating units (such as coal-, oil-, and gas-fired, plus nuclear) operated by the same utility. If a unit in our sample is jointly owned by more than one electric utility, we consider its majority owner only. Thus:

$$
\text { Categorical membership }=\frac{\# \text { of nuclear units operated by utility }}{\text { total } \# \text { of generating units operated by utility }}
$$

Although we did initially consider the yearly electricity generation by nuclear means over the total electricity generated in a year for each utility as an alternative measure for the same construct, we ultimately had to discard it as it was not as reflective of categorical membership as the one we ultimately chose ${ }^{7}$. This is because energy production constantly fluctuates to meet demand, and since nuclear power plants are typically used to cover the so-called base load — i.e. the minimum amount of power that must always be made available to customers—-the measure would have likely been biased, as fossil-fueled plants are typically either turned off or set to operate at reduced power when demand is low, while nuclear plants are required to maintain constant power levels to avoid equipment damage (Davis \& Wolfram, 2012).

Control variables. Because other factors can affect the decision to complete a planned unit or cancel it, we must include a set of controls in our study. To control for the fact that the chances of cancellation are likely to vary as time goes by, we include years since approval as a control variable. Moreover, it might be that technical considerations have a bearing in the decision, as well: to make sure that this is not an issue, we control for unit nameplate power, as well as the type of reactor (pressurized water reactor, boiled water reactor, or experimental). The Three Mile Island accident, which took place in Pennsylvania in 1979, had a substantial impact on strategic decisions made in the industry; as such, we control for it by means of a dummy variable which takes value 0 before 1979 and 1 afterwards. We also include dummies for whether there are: 1) other units under construction at same site; 2) other units planned at the same site; 3) other units planned by the same utility; 4) other units under construction by the same

from renewable sources; rather, after the passage of the Public Utility Regulatory Policies Act (PURPA), utilities typically purchased renewable energy from nonutility producers (Sine and Lee 2009).

${ }^{7}$ This variable is retained as a control. 
utility; 5) other units under construction in the same state; 6) other units planned in the same state; or 7) other units operating in the same state. ${ }^{8}$ This is because cost and time overruns in one project might hinder the construction of other units by the same utility, possibly resulting in cancellation; moreover, the presence of units (either planned or operational) in the same state might affect the local perception of nuclear power, as well as the perceived need for nuclear power in the state; and finally, the presence of other units (either operational or planned) at the same site has been found to affect projected costs (Komanoff 1982) and, presumably, chances of completion. To control for the fact that utilities of different size might make different decisions regarding the completion and cancellation of units, for instance due to their higher financial capacity, we control for utility size proxied by the total amount of electricity (expressed in MWh) generated by the utility in a given year'. Political effects at the state level might have a bearing on the fate of nuclear units in that state, for instance because politicians of a given party oppose nuclear power at a given moment in time: to control for this, we include a dummy for whether the state in which the unit is located has a Republican governor. The extent to which nuclear power generation is advantageous also depends on the availability of cheaper alternatives: if coal and oil prices rise, building nuclear units becomes more convenient. We thus include in the regression historical oil spot price and coal spot price figures, lagged by one year. Although some nuclear units have a single owner, most are jointly owned, i.e. several electric utilities hold shares in the same generating unit. The resulting resource pooling and risksharing may increase the chances of unit completion, while at the same time making utility-level decision-making processes more complex; in our analysis, therefore, we control for number of owners, which we model as a count variable, as well as for whether any of the utilities involved have public ownership. Experience in operating nuclear reactors is also likely to have a bearing on firm decisions: in our empirical study we measure it in reactor-years, so as to account for both the number of reactors operated in the past and the number of years for which they were operated, which is consistent with previous studies of the nuclear industry (Davis \& Wolfram, 2012; Lester \& McCabe, 1993). Finally, as we discussed previously, we include a control variable for social movement pressure at the state level, as well as a variable to track the share of nuclear energy generated by each utility (i.e. the ratio of

\footnotetext{
8 Two more dummy variables concerning operating units had to be dropped due to multicollinearity, most likely because they are highly correlated with experience measures discussed below.

${ }^{9}$ Most electric utilities are not public companies; finding financial information about them thus becomes a nearly impossible task.
} 
nuclear energy generated to the total amount of energy generated by the utility). Table 3 reports descriptive statistics for most of the variables listed thus far, as well as the relevant correlation coefficients. Unless otherwise specified, all of the control variables were lagged by one year.

[Table 2 - Descriptive statistics]

\section{Results}

Since our dependent variable is binary, we employ logistic regression to estimate our models. The expression for the probability of unit cancellation is thus nonlinear and it takes the following form:

$$
P=\frac{\exp \left(x_{i} \beta\right)}{1+\exp \left(x_{i} \beta\right)}
$$

where $P$ is the probability of cancellation, $x$ represents the set of covariates, and $\beta$ is the set of coefficients (including the constant). Table 3 reports the coefficients of five logistic regression models estimated by maximum likelihood: while Model 1 is the baseline model with control variables only, Model 2 adds media exposure and stigma intensity and Model 3 adds their interaction. Finally, Model 4 includes all of the main independent variables—exposure, stigma intensity, and extent of membership—but without interaction terms, while Model 5 is our full model.

[Table 3 - Logistic regression analysis of the probability of unit cancellation]

As far as our independent variables are concerned, Model 2 shows that stigma intensity is negatively associated with the likelihood of unit cancellation, which provides support for Hypothesis 1 . Model 3 adds the interaction effect between stigma intensity and exposure for the full model, which is depicted in Figure 4: the negative association between the dependent variable and stigma intensity is strongest when media exposure is low, which provides support for Hypothesis 2. Given its initial plateau at low levels of media exposure and sharp decline at medium to high levels of media exposure, the plot is very suggestive of the habituation effects previously described. 
[Figure 4 - Interaction effect between media exposure and stigma intensity for the full model]

Finally, Model 4 in Table 2 adds the extent of membership without the exposure-intensity interaction term, while Model 5 is our full model. The coefficient for the extent of membership is negative and significant in both models, in line with Hypothesis 3; moreover, all of the effects previously discussed remain significant when all independent variables and controls are included. As far as post-estimation is concerned, we calculated marginal effects for the two main independent variables in order to assess the size of the observed effects, and found that a one deviation increase in the extent of membership increases the odds of cancellation by approximately $13 \%$. Similarly, a one standard deviation increase in stigma intensity also increases the odds of cancellation by about $13 \%$ on average, but the magnitude of the effect is contingent on media exposure and it varies from a minimum of $5 \%$ to a maximum of $20 \%$.

The coefficients for some of the control variables are also worth discussing. Model 1 shows that planned reactors are less likely to be cancelled as time goes by; this suggests that most units which do not get cancelled within a few years of approval are ultimately completed, showing a tendency on the electric utilities' part to act early rather than late. Boiling-water reactors (BWR) are also found to be more likely to be cancelled vis-à-vis pressurized-water reactors, an effect which is probably due to the latter being a more mature technology. Experimental reactors, on the other hand, are probably too few to yield any meaningful result. The occurrence of the Three Mile Island accident is positively associated with the decision to cancel, as is previous experience in operating nuclear reactors by the proposing utility company. While being relatively small in magnitude, this latter effect is nonetheless surprising, since we would expect experienced utilities to be less likely to cancel due to their accumulated expertise in nuclear power generation. A tentative explanation could be that by the time most cancellations occurred, the prospects for nuclear power had already grown bleak due to cost and time overruns, stricter regulatory requirements and availability of cheaper energy sources (Davis, 2012). If this is the case, then (other things being equal) utilities with experience in operating reactors might have been in a better position to evaluate the feasibility of their open projects, thereby increasing the likelihood of cancellations.

\section{Robustness checks and alternative explanations}


Choice of models. We ran several tests to check whether our results would prove robust to the choice of variables, model specification, and alternative explanations. First of all, to show that our results do not depend on the choice of a logit model, we ran our full model (Model 5) again using a probit model (Model 6) and a linear probability model (Model 7). To account for the fact that cancellations might not be entirely independent events, i.e. that multiple units at the same site might be simultaneously cancelled, we also ran another logit model with standard errors clustered at the plant level, rather than conventional robust standard errors (Model 8). This is because under conditions of non-independence regression estimates are generally unbiased but the standard errors are likely to be wrong, possibly resulting in incorrect inference (Cameron \& Trivedi, 2005).

[Table 4 - Alternative model specifications with probit regression, LPM and standard errors clustered at the plant level]

Table 4 shows that our results do not differ significantly across models, which eases concerns about their robustness.

Fixed effects. To control for possible omitted variable bias due to unobserved factors, we ran additional models with the addition of: 1) state fixed effects, to rule out confounding factors based on geography; and 2) utility fixed effects, because utilities might differ in time-invariant, unobserved ways, for instance in terms of managerial ability or financial resources. We used a linear probability model (LPM) with robust standard errors for this task because the inclusion of fixed effects results in a relatively large number of covariates (in excess of 60 in both cases) with a relatively small number of observations $(N=214)$. Under these conditions, logistic regression is almost guaranteed not to achieve convergence (Peduzzi et al. 1996). On the other hand, the linear probability model (LPM) provides unbiased and consistent estimates when certain conditions are met and after robust standard errors have been added to the model to account for the heteroskedasticity arising from the OLS estimation of a binary variable (Horrace and Oaxaca 2006). The estimates for our complete LPM with fixed effects and robust standard errors are reported in Table 5. The pattern of results found in the previous model substantially holds and all of our hypotheses remain supported.

[Table 5 - Alternative LPM specifications with state fixed effects, utility fixed effects and robust standard errors] 
Ruling out cost-based alternative explanations. Finally, we must address what we regard as perhaps the most appealing alternative explanation for our findings: it might be that the variance in outcomes we observe in our sample is entirely due to cost factors, which we did not account for in our model. Reactors that are more expensive to build might in fact be more likely to get cancelled, and thus the effect we observe could potentially have nothing to do with either category membership or stigma intensity, thereby invalidating our assertions. The reason why we did not include capital cost data for each proposed unit is that such data are typically not available to the public, and whatever information might be available typically does not cover cancelled units. To approach the problem, therefore, we gathered cost data collected by Komanoff (1982) and Koomey \& Hultman (2007) to construct capital cost estimates for 84 proposed reactor units, about $39 \%$ of our sample. Our subsample is unbalanced in that 74 units were completed and only 10 were cancelled, but it does represent the best sample that could be assembled given the data at our disposal. To estimate capital cost for each unit, we used an empirical formula developed and tested by Komanoff (1982:199) on a sample of 46 reactors; the R-squared of the regression model based on the author's formula was found to be over $90 \%$. The capital cost estimates as calculated by Komanoff's formula are based on: 1) location; 2) whether there are multiple units at the same site; 3) architect-engineer experience; 3) unit size (in MW); 4) presence of a cooling tower; 5) whether the unit was dangling, i.e. there were other incomplete units at the same site at the time of analysis, due to higher costs being allocated to the first unit; and 6) cumulative nuclear capacity, i.e. the total size of the nuclear energy sector. In line with the author's methodology, our cost data is mid-1979 dollars excluding interest. ${ }^{10}$ After calculating a capital cost estimate for each of the 84 reactors in the subsample, we performed a t-test of the cancelled units (mean $=$ 751.7, SD = 106.8) vis-à-vis the completed ones (mean = 697.0, SD = 206.2); the differences in average capital costs between the two groups turned out to be not significant $[\mathrm{t}(82)=0.82, \mathrm{p}<.4142]$. This result suggests that, while cost issues are fully expected to play a role in firm decisions concerning the completion of planned units, the extent of their effect is likely not such to warrant a reconsideration of our findings.

\section{Discussion}

${ }^{10}$ Further details about the methodology are available from the authors. 
As a topic of inquiry, organizational stigma is enjoying an ever-increasing popularity in the organizational sciences (Devers et al. 2009, Hudson and Okhuysen 2014, Link and Phelan 2001). While considerable theoretical and empirical efforts have been devoted to clarifying how the negative consequences of stigma arise and diffuse across social actors (Jonsson et al. 2009, Pontikes et al. 2010), the behavior of organizations that face stigma is not yet well understood. Specifically, while extant research has examined symbolic responses such as defensive practice adoption or impression management techniques (Carberry and King 2012, Desai 2011, McDonnell and King 2013) as well as coping strategies such as concealment tactics or boundary management processes (Hudson and Okhuysen 2009), more substantive responses such as disengagement or outright defection from controversial lines of activity have not been thoroughly investigated. Our paper thus adds to the literature by looking into the determinants of this decision, i.e. whether to reduce the organization's involvement in a contested practice. Drawing on data about all proposed new nuclear units to be built in the United States between 1970 and 2000, we found clear evidence that organizations are more likely to abandon their plans to construct a new unit—-thereby disengaging from the category—when their membership in the nuclear power generation category is marginal. At the same time, higher stigma intensity also results in a higher likelihood of defection, and all the more so when the media exposure of the category is low.

Our findings contribute to the literature on organizational stigma (Devers et al. 2009) in several ways. First, we make the argument that when organizations are involved to a significant extent in a category that is socially disapproved, identity concerns will be triggered, making social actors less likely to disengage from identity-defining lines of activity. On one hand, this is somewhat counterintuitive in that organizations whose involvement in contested practices is substantial are likely to be the most stigmatized (Vergne 2012); yet, as their extent of their involvement increases, identity considerations become more and more likely to keep them in place, making defection problematic. On the other hand, this result is in line with recent findings that highlight the crucial role played by organizational identity in shaping firm behavior: for instance, in a study of corporate law firms, Phillips, Turco, \& Zuckerman (2013) found that identity considerations effectively create a barrier to diversification, preventing law firms from expanding into certain practice areas. Even though our own findings in this regard are specular — in that identity considerations prevent firms from leaving a stigmatized category, rather 
than entering it - they nonetheless corroborate the idea that identity-based dynamics are often at work to constrain organizational opportunities for action. While alternative explanations can be advanced for this finding, in our view none of them appears particularly compelling, given the specificities of our empirical setting. Escalation of commitment is unlikely to account for our findings, given that they hold even after controlling for experience. Inertia-based arguments (Hannan and Freeman 1984), whereby organizations are too entrenched in their ways to disengage from activities they have been engaged in for a long time, in our view fall short because nuclear power is a relatively new technology compared to its main alternatives, i.e. fossil-fuel and hydroelectric power generation. Similarly, we contend that economic arguments concerning sunk costs have limited appeal because these do not vary significantly across projects.

Second, organizations are found to be quite responsive to varying level of stigma intensity-i.e. disapproval - targeting a category to which they belong, despite not being attacked directly. While the extant literature has acknowledged that stigma can vary in degree or strength (Hudson and Okhuysen 2009, Hudson 2008) and many empirical studies have investigated firm responses to media attacks that target them (Durand and Vergne in-press), we offer evidence that organizations take macro-level stakeholder disapproval of a practice just as seriously, even though stigma affects them only vicariously through their categorical affiliation. When the stigma targeting a category becomes more intense, organizational decision-makers face increasing pressure to take action, and therefore the likelihood of disengagement increases. This suggests that perhaps greater attention should be paid to the role played by the field-level processes of stigmatization in shaping organization-level behavior, which has been significantly underexplored so far.

Third, we show that media exposure plays a critical role in shaping firm responses to categorical stigma. Our results in fact suggest that organizations will choose whether to act on the disapproving signals conveyed to them through the media based on the volume of coverage a stigmatized category receives. More specifically, we show that as the amount of information available about the category in the media increases, the likelihood to disengage from it declines. This reflects both the cognitive limitations of humans, who are subject to information overload (Pashler, 1999), and the effects of habituation to a repeated stimulus (Berlyne, 1951). These findings run counter to much conventional wisdom regarding the expected effects of media exposure on organizational 
responses (Carberry and King 2012, Durand and Vergne in-press), which would predict that increased media coverage of a stigmatized practice would spur involved organizations into action. Yet our study shows that it is important to separate the content of coverage from the volume of coverage: while the impact of media coverage on organizational decisions and outcomes is relatively uncontroversial, our findings specify the conditions under which stigma is most likely to induce a response. Along the same lines, our results also enhance scholarly understanding of the role that the media - and publicity more generally - play in broadcasting and reinforcing stigma (e.g. Clemente and Roulet in-press).

Although our findings carry potentially important implications for organizational theory, they must be viewed in light of their limitations. First of all, the empirical setting chosen severely limited our sample size: since the number of new nuclear reactor units proposed in the United States is relatively small, and an even smaller number of electric utility companies are involved in nuclear power generation, we had to rely on a sample of about 200 observations. While this does not constitute a problem per se, it inevitably restricts the range of hypotheses that can be tested simultaneously, thus limiting the scope of our theory. Another limitation of our study is that, due to the unavailability of reliable cost data for reactor projects that were abandoned, our treatment of cost-based alternative explanations was necessarily incomplete. Even though we are unable to provide an estimate of the magnitude of the effect that issues such as cost escalation have on the decision to abandon a particular project, our robustness checks suggest that this is most likely not a reason for concern with respect to our findings. Moreover, the nature of our study does not allow for a dynamic analysis of media effects, which prevents us from delving deeper into the empirical nuances of the interaction between media exposure and stigma intensity. While our results are fairly clear-cut, further scholarly efforts should be devoted to understanding the temporal dynamics of media attention. Finally, since our dependent variable of interest was the firm-level decision to abandon a particular project, we had to eliminate from the sample all projects whose cancellation was decided by local governments or by courts of law. Even though leaving them out was necessary to obtain a clean empirical setting, their presence reflects the fact that powerful political and institutional dynamics are most likely at work, especially given the contentiousness of nuclear power-which persists to this day — and the prominent role that social movement organizations have played in its downfall (King and Pearce 
2010). We believe these dynamics are important and as such, further research should be devoted to modelling them explicitly and integrating them into a more comprehensive theoretical model of categorical stigma aimed at explaining what causes field-level stigmatization of certain activities and practices to occur in the first place. 


\section{References}

Alexy, O., G. George. 2013. Category Divergence, Straddling, and Currency: Open Innovation and the Legitimation of Illegitimate Categories. J. Manag. Stud. 50(2) 173-203.

Anspach, R. R. 1979. From stigma to identity politics: Political activism among the physically disabled and former mental patients. Social Science \& Medicine. Part A: Medical Psychology \& Medical Sociology, 13: 765-773.

Anteby, M. 2010. Markets, Morals, and Practices of Trade: Jurisdictional Disputes in the U.S. Commerce in Cadavers. Adm. Sci. Q. 55(4) 606-638.

Berelson, B. 1948. Communications and public opinion. W. Schramm, ed. Commun. Mod. Soc. Urbana, IL, University of Illinois Press, 167-185.

Berlyne, D. E. 1951. Attention to change. Br. J. Psychol. 42(3) 269-278.

Carberry, E. J., B. G. King. 2012. Defensive Practice Adoption in the Face of Organizational Stigma: Impression Management and the Diffusion of Stock Option Expensing. J. Manag. Stud. 49(7) 1137-1167.

Clemente, M., T. Roulet. in-press. Public Opinion as a Source of Deinstitutionalization: A "Spiral of Silence" Approach. Acad. Manag. Rev.

Crocker, J., Major, B., Steele, C. 1998. Social stigma: the psychology of marked relationships. In S. Fiske, D. Gilbert, G. Lindzey (eds.) The handbook of social psychology, 504-553. Boston:McGraw-Hill.

Davis, B. L. W., C. Wolfram. 2012. Deregulation, Consolidation, and Efficiency: Evidence from US Nuclear Power. Am. Econ. J. Appl. Econ. 4(4) 194-225.

Davis, L. W. 2012. Prospects for Nuclear Power. J. Econ. Perspect. 26(1) 49-66.

Deephouse, D. L. 1996. Does Isomorphism Legitimate? Acad. Manag. J. 39(4) 1024-1039.

Desai, V. M. 2011. Mass Media and Massive Failures: Determining Organizational Efforts To Defend Field Legitimacy Following Crises. Acad. Manag. J. 54(2) 263-278.

Devers, C. E., T. Dewett, Y. Mishina, C. A. Belsito. 2009. A General Theory of Organizational Stigma. Organ. Sci. 20(1) 154-171.

Downs, A. 1972. Up and down with ecology: The issue attention cycle. Public Interest 28(1) 38-50.

Durand, R., J.-P. Vergne. in-press. Asset Divestment as a Response to Media Attacks in Stigmatized Industries. Strateg. Manag. J.

Ebbinghaus, H. 1913. Memory: A contribution to experimental psychology. New York, Teachers College, Columbia University.

Elsbach, K. D. 1994. Managing Organizational Legitimacy in the California Cattle Industry: The Construction and Effectiveness of Verbal Accounts. Adm. Sci. Q. 39(1) 57.

Elsbach, K. D., C. B. Bhattacharya. 2001. Defining Who You Are by What You're Not: Organizational Disidentification and the National Rifle Association. Organ. Sci. 12(4) 393-413.

Elsbach, K. D., R. M. Kramer. 1996. Members' Responses to Organizational Identity Threats : Encountering and Countering the Business Week Rankings. Adm. Sci. Q. 41(3) 442-476.

Elsbach, K. D., R. I. Sutton. 1992. Acquiring Organizational Legitimacy Through Illegitimate Actions: a Marriage of Institutional and Impression Management Theories. Acad. Manag. J. 35(4) 699-738.

Erikson, K. T. 1961. Notes on the Sociology of Deviance. Soc. Probl. 9 307-314.

Fleiss, J. L. 1981. Statistical Methods for Rates and Proportions. New York, Wiley.

Fombrun, C., M. Shanley. 1990. What's in a Name? Reputation Building and Corporate Strategy. Acad. Manag. J. 33(2) 233-258.

Gamson, W. A. 1988. A constructionist approach to mass media and public opinion. Symb. Interact. 11 161-174.

Gamson, W. A., A. Modigliani. 1989. Media Discourse and Public Opinion on Nuclear Power: A Constructionist Approach. Am. J. Sociol. 95(1) 1-37.

Gioia, D. A., S. D. Patvardhan, A. L. Hamilton, K. G. Corley. 2013. Organizational Identity Formation and Change. Acad. Manag. Ann. 7(1) 123-192.

Glynn, M. A., Marquis, C. 2004. When good names go bad: Symbolic illegitimacy in organizations. Research in the Sociology of Organizations, 22: 147-170.

Goffman, I. 1963. Stigma: Notes on the Management of Spoiled Identity. New York, NY, Prentice-Hall.

Greve, H. R., D. Palmer, J.-E. Pozner. 2010. Organizations Gone Wild: The Causes, Processes, and Consequences of Organizational Misconduct. Acad. Manag. Ann. 4(1) 53-107. 
Gurevitch, M., M. E. Levy. 1985. Mass Communication Review Yearbook. Beverly Hills, CA, SAGE.

Hannan, M. T. 2010. Partiality of Memberships in Categories and Audiences. Annu. Rev. Sociol. 36(1) 159-181.

Hannan, M. T., J. H. Freeman. 1984. Structural Inertia and Organizational Change. Am. Sociol. Rev. 49(2) 149-164.

Hirsh, R. F. 1999. Power Loss: The Origins of Deregulation and Restructuring in the American Electric Utility System. Boston, MA, The MIT Press.

Hoffman, A. J., W. Ocasio. 2001. Not All Events Are Attended Equally: Toward a Middle-Range Theory of Industry Attention to External Events. Organ. Sci. 12(4) 414-434.

Horlick-Jones, T., A. Prades, J. Espluga. 2012. Investigating the Degree of "Stigma” Associated with Nuclear Energy Technologies: A Cross-Cultural Examination of the Case of Fusion Power. Public Underst. Sci. 21(5) 514-33.

Horrace, W. C., R. L. Oaxaca. 2006. Results on the Bias and Inconsistency of Ordinary Least Squares for the Linear Probability Model. Econ. Lett. 90 (3) 321-327.

Hsu, G. 2006. Jacks of All Trades and Masters of None: Audiences' Reactions to Feature Film Production. Adm. Sci. Q. 51(3) 420-450.

Hsu, G., K. D. Elsbach. 2013. Explaining Variation in Organizational Identity Categorization. Organ. Sci. 1-18.

Hsu, G., M. T. Hannan, O. Kocak. 2009. Multiple Category Memberships in Markets: An Integrative Theory and Two Empirical Tests. Am. Sociol. Rev. 74(1) 150-169.

Hudson, B. A. 2008. Against All Odds: A Consideration Of Core-Stigmatized Organizations. Acad. Manag. Rev. 33(1) 252-266.

Hudson, B. A., G. A. Okhuysen. 2009. Not with a Ten-Foot Pole: Core Stigma, Stigma Transfer, and Improbable Persistence of Men's Bathhouses. Organ. Sci. 20(1) 134-153.

Hudson, B. A., G. A. Okhuysen. 2014. Taboo Topics: Structural Barriers to the Study of Organizational Stigma. J. Manag. Inq. 23(3) 242-253.

Jones, E., Farina, A., Hastorf, A., Markus, H., Miller, D., Scott, R. 1984. Social stigma: The psychology of marked relationships. New York: WH Freeman.

Jonsson, S., H. Buhr. 2010. The Limits of Media Effects: Field Positions and Cultural Change in a Mutual Fund Market. Organ. Sci. 22(2) 464-481.

Jonsson, S., H. R. Greve, T. Fujiwara-Greve. 2009. Undeserved Loss: The Spread of Legitimacy Loss to Innocent Organizations in Response to Reported Corporate Deviance. Adm. Sci. Q. 54(2) 195.

Kennedy, M. T. 2005. Behind the One-Way Mirror: Refraction in the Construction of Product Market Categories. Poetics 33(3-4) 201-226.

King, B. G., N. A. Pearce. 2010. The Contentiousness of Markets: Politics, Social Movements, and Institutional Change in Markets. Annu. Rev. Sociol. 36(1) 249-267.

Komanoff, C. 1982. Power Plant Cost Escalation: Nuclear and Coal Capital Cost, Regulation, and Economics. Van Nostrand Reinhold.

Koomey, J. G., N. E. Hultman. 2007. A Reactor-Level Analysis of Busbar Costs for US Nuclear Plants, 1970-2005. Energy Policy 35(11) 5630-5642.

Lang, K., G. E. Lang. 1966. The mass media and voting. B. Berelson, M. Janovitz, eds. Read. public Opin. Commun. New York, NY, Free Press, 455-472.

Lawrence, T. B., R. Suddaby, B. Leca. 2011. Institutional Work: Actors and Agency in Institutional Studies of Organizations. Cambridge, UK, Cambridge University Press.

Lazarsfeld, P. A., R. K. Merton. 1948. Mass communication, popular taste and organized social action. L. Bryson, ed. Commun. Ideas A Ser. Addresses. New York, NY, Harper, 95-118.

Lester, R. K., M. J. McCabe. 1993. The Effect of Industrial Structure on Learning By Doing in Nuclear Power Plant Operation. RAND J. Econ. 24(3) 418-438.

Link, B. G., J. C. Phelan. 2001. Conceptualizing Stigma. Annu. Rev. Sociol. 27(1) 363-385.

Lounsbury, M., H. Rao. 2004. Sources of Durability and Change in Market Classifications: A Study of the Reconstitution of Product Categories in the American Mutual Fund Industry, 1944-1985. Soc. Forces 82(3) 969999.

Maguire, S., C. Hardy, T. B. Lawrence. 2004. Institutional Entrepreneurship in Emerging Fields: HIV/AIDS Treatment Advocacy in Canada. Acad. Manag. J. 47(5) 657-679.

Major, B., O'Brien, L. T. 2005. The social psychology of stigma. Annu. Rev. Psychol., 56: 393-421.

Malinowski, B. 1926. Crime and custom in savage society. New York, NY, Harcourt. 
Marquis, C., Z. Huang. 2010. Acquisitions As Exaptation: The Legacy of Founding Institutions in the U.S. Commercial Banking Industry. Acad. Manag. J. 53(6) 1441-1473.

Matza, D. 1969. Becoming deviant. Englewood Cliffs, NJ, Prentice-Hall.

McCombs, M. E., D. L. Shaw. 1972. The agenda-setting function of mass media. Public Opin. Q. 26 176-187.

McDonnell, M.-H., B. G. King. 2013. Keeping up Appearances: Reputational Threat and Impression Management after Social Movement Boycotts. Adm. Sci. Q. 58(3) 387-419.

Meyer, J. W., B. Rowan. 1977. Institutionalized Organizations: Formal Structure as Myth and Ceremony. Am. J. Sociol. 83(2) 340-363.

Mitchell, D.-G. 2014. Here Today, Gone Tomorrow? Assessing How Timing and Repetition of Scandal Information Affects Candidate Evaluations. Polit. Psychol. 35(5) 679-701.

Negro, G., O. Kocak, G. Hsu. 2010. Research on Categories in the Sociology of Organizations. Res. Sociol. Organ. 31(2010) 3-35.

Pashler, H. E. 1999. The psychology of attention. Cambridge, MA, MIT Press.

Peduzzi, P., J. Concato, E. Kemper, T. R. Holford, A. R. Feinstein. 1996. A Simulation Study of the Number of Events per Variable in Logistic Regression Analysis. J. Clin. Epidemiol. 49(12) 1373-1379.

Pfarrer, M. D., K. A. Decelles, K. G. Smith, M. S. Taylor. 2008. After the Fall: Reintegrating the Corrupt Organization. Acad. Manag. Rev. 33(3) 730-749.

Phillips, D. J., C. J. Turco, E. W. Zuckerman. 2013. Betrayal as Market Barrier: Identity-Based Limits to Diversification among High-Status Corporate Law Firms. Am. J. Sociol. 118(4) 1023-1054.

Pontikes, E., G. Negro, H. Rao. 2010. Stained Red: A Study of Stigma by Association with Blacklisted Artists during the "Red Scare" in Hollywood, 1945-1960. Am. Sociol. Rev. 75(3) 456.

Porac, J. F., J. B. Wade, T. G. Pollock. 1999. Industry Categories and the Politics of the Comparable Firm in CEO Compensation. Adm. Sci. Q. 44(1) 112-144.

Rhee, M., M. E. Valdez. 2009. Contextual Factors Surrounding Reputation Damage with Potential Implications for Reputation Repair. Acad. Manag. Rev. 34(1) 146-168.

Rosch, E. 1978. Principles of Categorization. E. Rosch, B. B. Lloyd, eds. Cogn. Categ. Hillsdale, NJ, Erlbaum, $27-48$.

Ross, J., B. M. Staw. 1993. Organizational Escalation and Exit: Lessons from the Shoreham Nuclear Power Plant. Acad. Manag. J. 36(4) 701-732.

Ruef, M., K. Patterson. 2009. Credit and Classification: The Impact of Industry Boundaries in Nineteenth-century America. Adm. Sci. Q. 54(3) 486-520.

Ruef, M., W. R. Scott. 1998. A Multidimensional Model of Organizational Legitimacy: Hospital Survival in Changing Institutional Environments. Adm. Sci. Q. 43(4) 877-904.

Selznick, P. 1949. TVA and the Grass Roots: A Study in the Sociology of Formal Organization. Berkeley, CA, University of California Press.

Sine, W. D., B. H. Lee. 2009. Tilting at Windmills? The Environmental Movement and the Emergence of the U.S. Wind Energy Sector. Adm. Sci. Q. 54(1) 123-155.

Staw, B. M. 1976. Knee-Deep in the Big Muddy: A Study of Escalating Commitment to a Chosen Course of Action. Organ. Behav. Hum. Perform. 16(1) 27-44.

Suchman, M. C. 1995. Managing Legitimacy: Strategic and Institutional Approaches. Acad. Manag. Rev. 20(3) 571-610.

Sutton, R. I., A. L. Callahan. 1987. The Stigma of Bankruptcy: Spoiled Organizational Image and Its Management. Acad. Manag. J. 30(3) 405-436.

Tost, L. P. 2011. An Integrative Model of Legitimacy Judgments. Acad. Manag. Rev. 36(4) 686-710.

Vergne, J.-P. 2012. Stigmatized Categories and Public Disapproval of Organizations: A Mixed Methods Study of the Global Arms Industry (1996-2007). Acad. Manag. J. 55(5) 1027-1052.

Vergne, J.-P., R. Durand. 2010. The Missing Link Between the Theory and Empirics of Path Dependence: Conceptual Clarification, Testability Issue, and Methodological Implications. J. Manag. Stud. 47(4) 736-759.

Walker, J. S. 2006. Three Mile Island: A Nuclear Crisis in Historical Perspective. Berkeley, CA, University of California Press.

Watt, J. H., S. Van den Berg. 1981. How time dependency influences media effects in a community controversy. Journal. Q. 58 43-50.

Watt, J. H., M. Mazza, L. Snyder. 1993. Agenda-setting effects of television news coverage and the effects decay curve. Communic. Res. 20(3) 408-435. 
Weaver, D. H., D. A. Graber, M. E. McCombs, C. H. Eyal. 1981. Media agenda-setting in a presidential election: Issues, images, and interest. New York, NY, Praeger.

Wellock, T. 1998. Critical Masses: Opposition to Nuclear Power in California, 1958-1978. The University of Wisconsin Press.

Westphal, J. D., E. J. Zajac. 1994. Substance and Symbolism in CEOs' Long-Term Incentive Plans. Adm. Sci. Q. 39(3) 367-390.

Westphal, J. D., E. J. Zajac. 1998. The Symbolic Management of Stockholders: Corporate Governance Reforms and Shareholder Reactions. Adm. Sci. Q. 43(1) 127-153.

Whetten, D. A. 2006. Albert and Whetten Revisited: Strengthening the Concept of Organizational Identity. J. Manag. Inq. 15(3) 219-234.

Woodworth, R. S., H. Schlosberg. 1954. Experimental Psychology 3rd ed. New York, NY, Holt.

Zavyalova, A., M. D. Pfarrer, R. K. Reger, D. L. Shapiro. 2012. Managing the Message: The Effects of Firm Actions and Industry Spillovers on Media Coverage Following Wrongdoing. Acad. Manag. J. 55(5) 1079-1101.

Zollo, M., H. Singh. 2004. Deliberate Learning in Corporate Acquisitions: Post-Acquisition Strategies and Integration Capability in U.S. Bank Mergers. Strateg. Manag. J. 25(13) 1233-1256.

Zucker, H. G. 1978. The variable nature of news media influence. B. D. Ruben, ed. Commun. Yearb. New Brunswick, NJ, Transaction Publishers, 225-240.

Zuckerman, E. W. 1999. The Categorical Imperative: Securities Analysts and the Illegitimacy Discount. Am. J. Sociol. 104(5) 1398-1397.

Zuckerman, E. W., T.-Y. Kim, K. Ukanwa, J. von Rittmann. 2003. Robust Identities or Nonentities? Typecasting in the Feature Film Labor Market. Am. J. Sociol. 108(5) 1018-1073. 
Figure 1. Nuclear power units ordered, connected, decommissioned and cancelled in the U.S. by year.

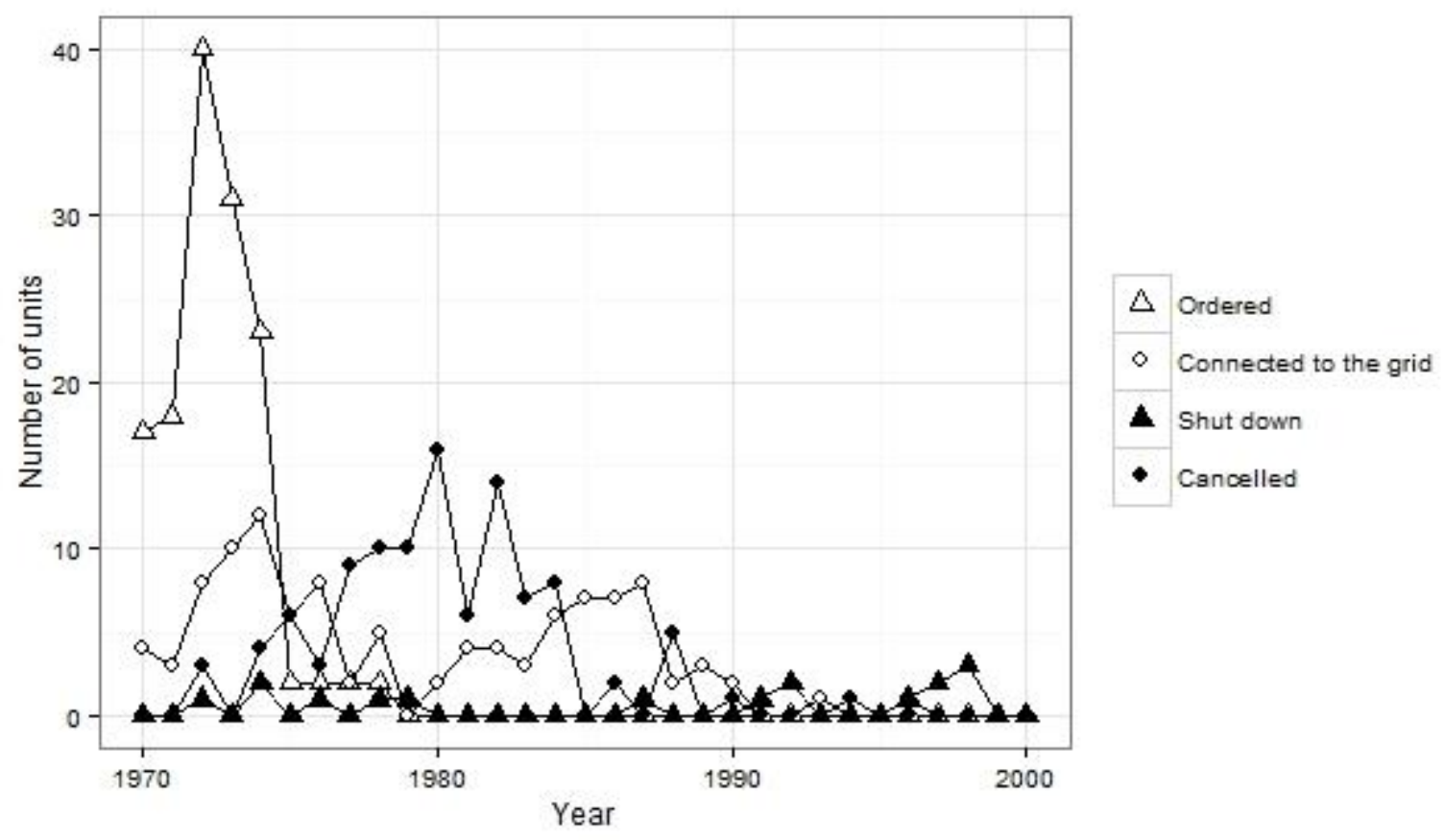

Figure 2. Cumulative number of nuclear units in the U.S. by stage of development and by year.

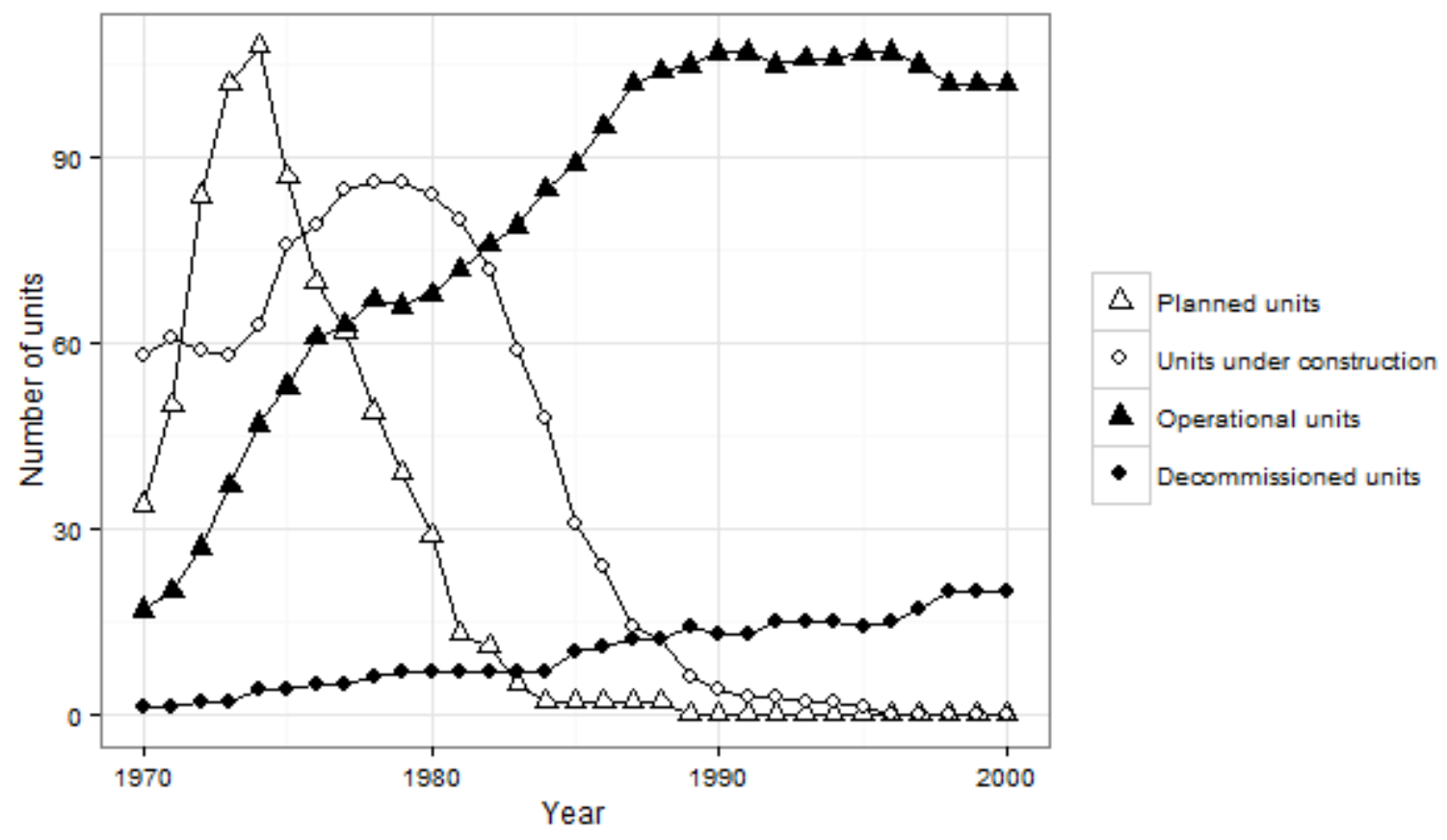


Figure 3. Number of New York Times articles about domestic nuclear energy issues, by type of coverage and by year.

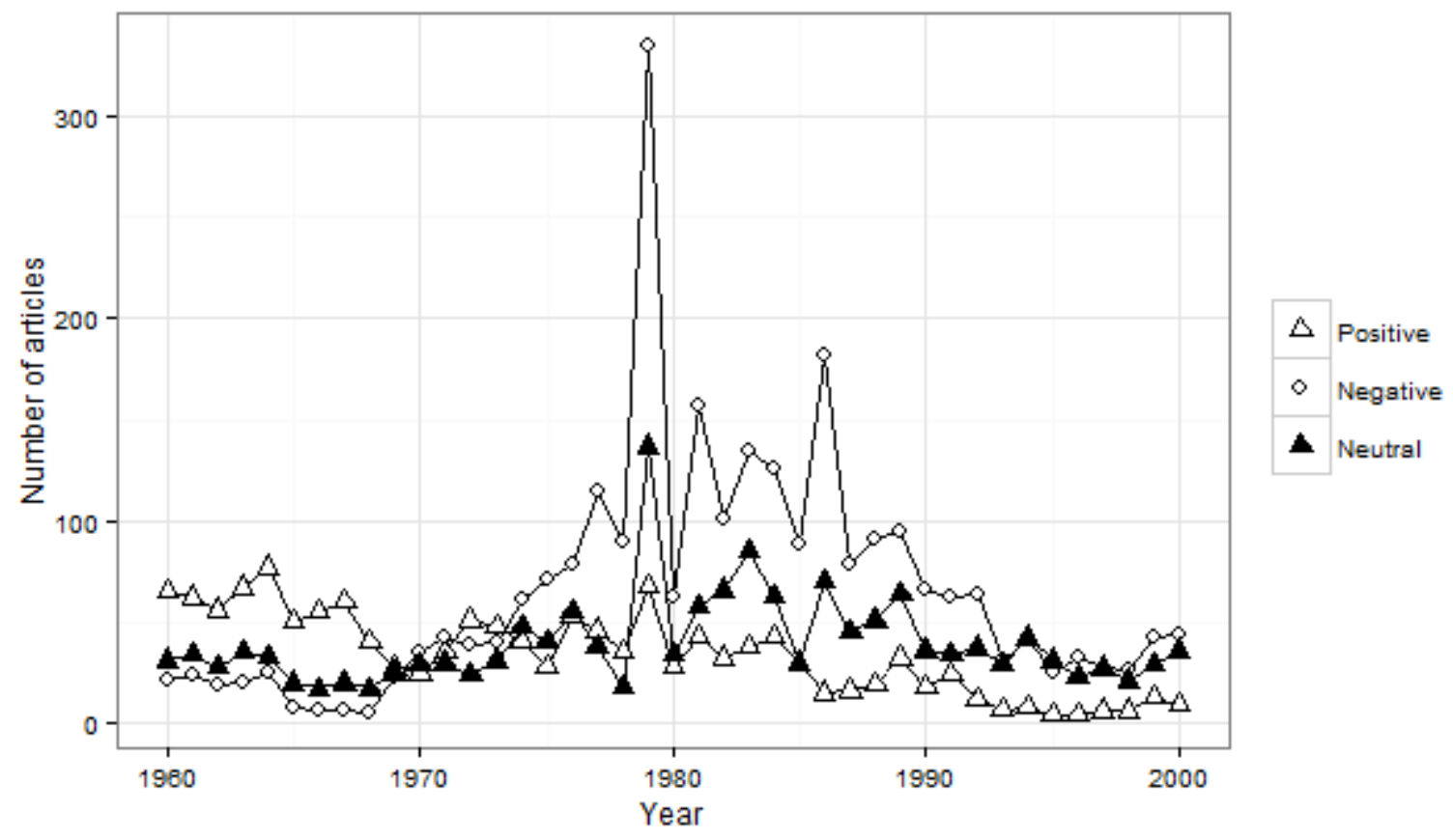

Figure 4. Interaction effect between media exposure and stigma intensity for the full logistic model.

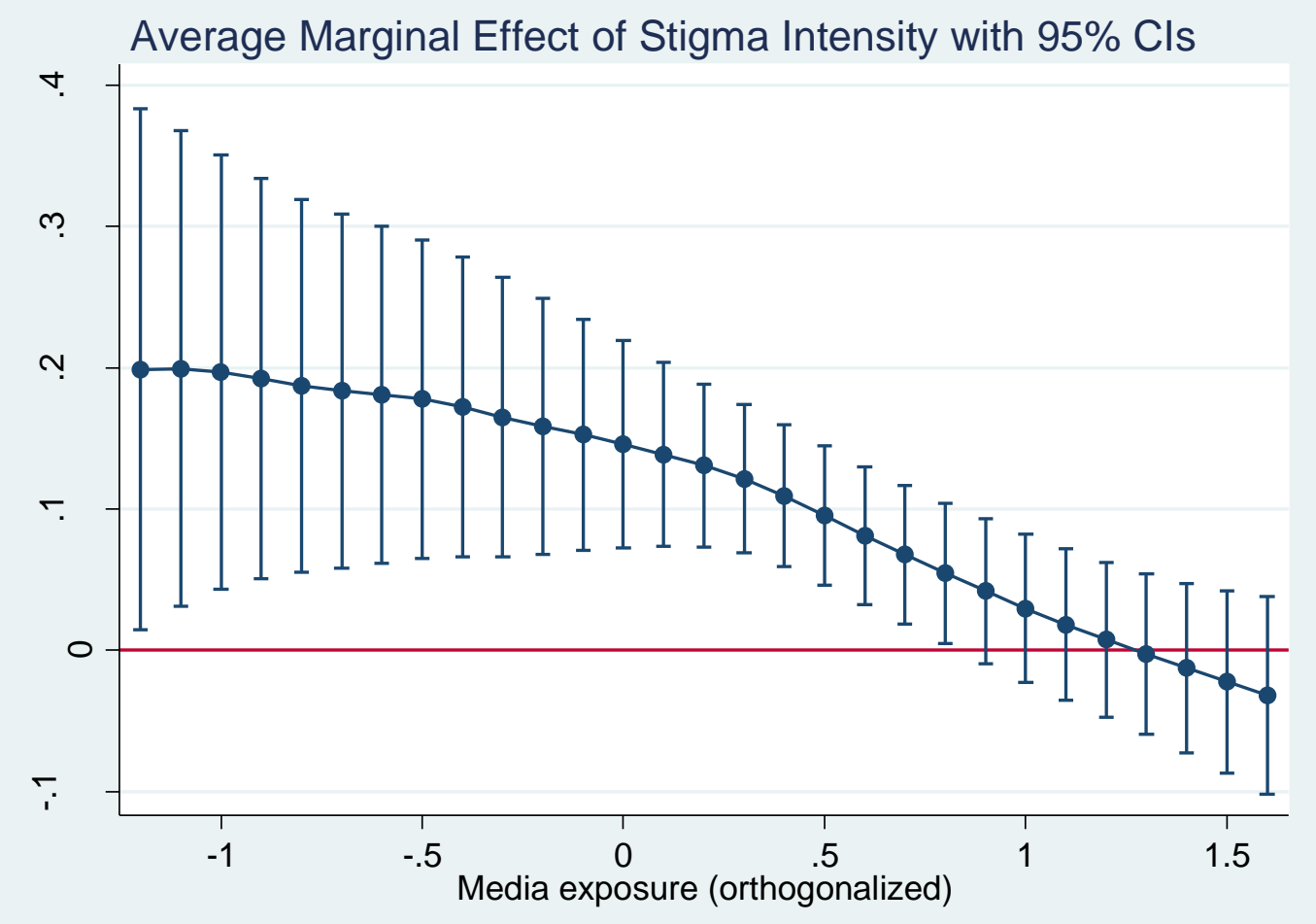


Table 1. Coding guidelines for newspaper articles.

Type of media coverage

Positive

Neutral
Definition
The article challenges the legitimacy of nuclear power by reporting on public opposition, discussing technological pitfalls, covering accidents or generally presenting critical viewpoints.

The article reinforces the legitimacy of nuclear power by painting it in a progressive light,

highlighting technological accomplishments, and generally presenting supportive viewpoints.

The article either reports on nuclear-related facts that do not have any immediate connotation or offers a balanced perspective which allots equal space to positive and negative viewpoints.
"As it nears completion, the Shoreham Nuclear Power Station on Long Island is being cited as the local example of what industry experts say is the end of an era of reactor construction in the United States. The demise of nuclear reactors is in sight, these experts say, because of two factors: rising costs and a reduction in the growth of the demand for power."

"Four employees at the Hanford Nuclear Reservation were found to have been contaminated with plutonium Thursday after radiation detection alarms were set off by one of the workers, a spokesman said today. Bill Klink, a spokesman for Rockwell Hanford Operations, said the source of the contamination at the Plutonium Finishing Plant was not known and that the incident was being investigated."

"According to a soon-to-be-published survey of scientifically trained persons carried out under the auspices of Smith College and Columbia University's Research Institute of International Change, 90 percent of scientists would proceed with nuclear energy. Seven out of 10 energy experts, including 92 percent of scientists in disciplines related to nuclear energy, favor the rapid development of nuclear energy."

"The moratorium that has prevented any new nuclear power plants in the United States from going into operation since the accident at Three Mile Island is approaching an end.

Tomorrow, the Nuclear Regulatory Commission is scheduled to consider an application for a plant from the Virginia Electric and Power Company, and the commission is thought to be satisfied that safety procedures have been tightened sufficiently to resume licensing new plants for full power operations."

"A simulated accident at the Indian Point 3 nuclear reactor produced a mock evacuation of Rockland County one night last week. Although no citizens left their homes and only a handful of buses and ambulances rolled, state and utility officials said they had learned enough to feel confident they could run a safe evacuation in an emergency."

"The State Department of Public Utility Control has decided to hire a consultant to audit the construction of the $\$ 3.54$ billion Millstone III nuclear power plant in Waterford. The department decided Thursday to study Northeast Utilities' construction of the plant, with the results of the audit to be used to determine which costs should be passed on to ratepayers. The plant is scheduled to go into service in 1986." 
Table 2. Descriptive statistics and pairwise correlations.

1 Duration of project

2 Unit power

3 Three Mile Island (dummy)

4 Utility size in MWh (logged)

5 Republican governor (dummy)

6 Oil price

7 Coal price

8 Number of owners

9 Public ownership (dummy)

10 Experience

11 Nuclear energy share

12 Social movement pressure

13 Stigma intensity (orthogonalized)

14 Media exposure (orthogonalized)

15 Extent of membership

\begin{tabular}{|c|c|c|c|c|c|c|c|c|c|c|c|c|c|c|c|c|c|c|}
\hline Mean & S.D. & Min & Max & 1 & 2 & 3 & 4 & 5 & 6 & 7 & 8 & 9 & 10 & 11 & 12 & 13 & 14 & 15 \\
\hline 9.472 & 4.796 & 0 & 26 & 1 & & & & & & & & & & & & & & \\
\hline 1045.6 & 198.64 & 330 & 1317 & 0.145 & 1 & & & & & & & & & & & & & \\
\hline 0.523 & 0.501 & 0 & 1 & 0.696 & 0.419 & 1 & & & & & & & & & & & & \\
\hline 23.723 & 1.28 & 18.217 & 25.544 & 0.167 & 0.129 & 0.06 & 1 & & & & & & & & & & & \\
\hline 0.425 & 0.496 & 0 & 1 & 0.192 & 0.062 & 0.215 & -0.13 & 1 & & & & & & & & & & \\
\hline 55.298 & 24.793 & 20.04 & 105.84 & 0.148 & 0.362 & 0.593 & -0.02 & -0.02 & 1 & & & & & & & & & \\
\hline 44.734 & 10.124 & 23.07 & 57.6 & -0.18 & 0.297 & 0.063 & -0.04 & -0.17 & 0.711 & 1 & & & & & & & & \\
\hline 1.701 & 1.743 & 1 & 11 & 0.139 & 0.045 & 0.03 & -0.16 & -0.02 & -0.2 & -0.21 & 1 & & & & & & & \\
\hline 0.136 & 0.343 & 0 & 1 & 0.089 & 0.14 & 0.104 & -0.08 & 0.157 & 0.059 & -0.05 & -0.16 & 1 & & & & & & \\
\hline 13.121 & 19.729 & 0 & 96 & 0.514 & 0.252 & 0.449 & 0.208 & 0.14 & 0.044 & -0.14 & 0.075 & 0.124 & 1 & & & & & \\
\hline 0.116 & 0.185 & 0 & 1 & 0.067 & 0.035 & 0.048 & -0.26 & 0.008 & 0.053 & 0.104 & -0.03 & -0.03 & 0.189 & 1 & & & & \\
\hline 0.874 & 2.764 & 0 & 32 & 0.058 & 0.105 & 0.123 & -0.04 & -0.06 & 0.158 & 0.149 & -0.02 & -0.11 & 0.005 & 0.078 & 1 & & & \\
\hline 0 & 1.002 & -1.815 & 2.705 & 0.518 & 0.207 & 0.27 & 0.09 & 0.069 & -0.18 & -0.12 & 0.221 & 0.008 & 0.436 & -0.01 & 0.063 & 1 & & \\
\hline 0 & 1.002 & -1.626 & 1.644 & 0.347 & 0.45 & 0.807 & 0.052 & 0.085 & 0.861 & 0.486 & -0.09 & 0.064 & 0.236 & 0.086 & 0.191 & 0 & 1 & \\
\hline 0.134 & 0.16 & 0 & 1 & 0.171 & 0.06 & 0.102 & -0.09 & 0.152 & -0.04 & -0.02 & 0.038 & -0.07 & 0.392 & 0.712 & -0.04 & 0.156 & 0.057 & \\
\hline
\end{tabular}


Table 3. Logistic regression analysis of the probability of unit cancellation.

\begin{tabular}{|c|c|c|c|c|c|}
\hline DV: unit cancellation & Model 1 & Model 2 & Model 3 & Model 4 & Model 5 \\
\hline Duration of project & $\begin{array}{l}-0.640 \\
(3.57)^{* * *}\end{array}$ & $\begin{array}{c}-0.950 \\
(4.75)^{* * *}\end{array}$ & $\begin{array}{c}-1.320 \\
(3.76)^{* * *}\end{array}$ & $\begin{array}{c}-1.004 \\
(4.28)^{* * *}\end{array}$ & $\begin{array}{l}-1.530 \\
(3.73)^{* * *}\end{array}$ \\
\hline Unit power (MW) & $\begin{array}{c}-0.001 \\
(0.24)\end{array}$ & $\begin{array}{l}-0.002 \\
(0.80)\end{array}$ & $\begin{array}{l}-0.006 \\
(1.51)\end{array}$ & $\begin{array}{l}-0.003 \\
(1.00)\end{array}$ & $\begin{array}{l}-0.008 \\
(1.69)\end{array}$ \\
\hline Unit type: BWR & $\begin{array}{l}1.074 \\
(2.36)^{*}\end{array}$ & $\begin{array}{l}1.786 \\
(2.53)^{*}\end{array}$ & $\begin{array}{l}2.319 \\
(2.42)^{*}\end{array}$ & $\begin{array}{l}2.239 \\
(2.51)^{*}\end{array}$ & $\begin{array}{l}3.455 \\
(2.61)^{* *}\end{array}$ \\
\hline Unit type: experimental & $\begin{array}{l}0.183 \\
(0.17)\end{array}$ & $\begin{array}{l}0.710 \\
(0.54)\end{array}$ & $\begin{array}{l}0.566 \\
(0.36)\end{array}$ & $\begin{array}{l}0.115 \\
(0.08)\end{array}$ & $\begin{array}{l}-0.176 \\
(0.11)\end{array}$ \\
\hline Three Mile Island (dummy) & $\begin{array}{l}6.033 \\
(3.36)^{* * *}\end{array}$ & $\begin{array}{l}7.701 \\
(3.63)^{* * * *}\end{array}$ & $\begin{array}{c}12.688 \\
(2.92)^{* *}\end{array}$ & $\begin{array}{l}8.687 \\
(3.47)^{* * *}\end{array}$ & $\begin{array}{c}15.037 \\
(3.13)^{* *}\end{array}$ \\
\hline \multirow{2}{*}{$\begin{array}{l}\text { Units under construction, same plant } \\
\text { (dummy) }\end{array}$} & 0.514 & 0.570 & 0.501 & 1.329 & 2.123 \\
\hline & $(0.73)$ & $(0.77)$ & $(0.66)$ & $(1.28)$ & $(1.70)$ \\
\hline Units planned, same plant (dummy) & $\begin{array}{l}6.418 \\
(5.65)^{* * *}\end{array}$ & $\begin{array}{l}6.640 \\
(5.31)^{* * *}\end{array}$ & $\begin{array}{l}8.177 \\
(4.72)^{* * *}\end{array}$ & $\begin{array}{l}6.997 \\
(4.78)^{* * * *}\end{array}$ & $\begin{array}{l}9.415 \\
(3.95)^{* * *}\end{array}$ \\
\hline \multirow{2}{*}{$\begin{array}{l}\text { Units under construction, same utility } \\
\text { (dummy) }\end{array}$} & -0.797 & -0.904 & -0.495 & -1.120 & -1.218 \\
\hline & $(0.78)$ & $(0.90)$ & $(0.48)$ & $(1.17)$ & $(1.23)$ \\
\hline Units planned, same utility (dummy) & $\begin{array}{l}-2.920 \\
(3.47)^{* * *}\end{array}$ & $\begin{array}{l}-1.818 \\
(1.87)\end{array}$ & $\begin{array}{l}-2.925 \\
(2.77)^{* *}\end{array}$ & $\begin{array}{l}-1.686 \\
(1.78)\end{array}$ & $\begin{array}{l}-2.880 \\
(2.84)^{* *}\end{array}$ \\
\hline \multirow{2}{*}{$\begin{array}{l}\text { Units under construction, same state } \\
\text { (dummy) }\end{array}$} & 0.712 & 0.803 & 1.155 & 0.088 & -0.147 \\
\hline & $(0.66)$ & $(0.75)$ & $(0.73)$ & $(0.09)$ & $(0.08)$ \\
\hline Units planned, same state (dummy) & $\begin{array}{l}-0.140 \\
(0.26)\end{array}$ & $\begin{array}{l}-1.155 \\
(1.05)\end{array}$ & $\begin{array}{l}-0.657 \\
(0.53)\end{array}$ & $\begin{array}{l}-0.383 \\
(0.29)\end{array}$ & $\begin{array}{l}0.531 \\
(0.38)\end{array}$ \\
\hline Operational units, same state (dummy) & $\begin{array}{l}0.245 \\
(0.38)\end{array}$ & $\begin{array}{l}0.617 \\
(0.95)\end{array}$ & $\begin{array}{l}0.918 \\
(1.20)\end{array}$ & $\begin{array}{l}0.687 \\
(1.06)\end{array}$ & $\begin{array}{l}1.328 \\
(1.58)\end{array}$ \\
\hline Utility size in MWh (logged) & $\begin{array}{l}-0.233 \\
(0.64)\end{array}$ & $\begin{array}{l}-0.292 \\
(0.86)\end{array}$ & $\begin{array}{l}-0.130 \\
(0.26)\end{array}$ & $\begin{array}{l}-0.321 \\
(0.90)\end{array}$ & $\begin{array}{l}-0.318 \\
(0.66)\end{array}$ \\
\hline Republican governor (dummy) & $\begin{array}{l}-0.453 \\
(0.88)\end{array}$ & $\begin{array}{l}-0.273 \\
(0.45)\end{array}$ & $\begin{array}{l}-0.257 \\
(0.43)\end{array}$ & $\begin{array}{l}-0.273 \\
(0.43)\end{array}$ & $\begin{array}{l}-0.205 \\
(0.35)\end{array}$ \\
\hline Oil price & $\begin{array}{l}-0.039 \\
(1.63)\end{array}$ & $\begin{array}{l}0.010 \\
(0.26)\end{array}$ & $\begin{array}{l}-0.026 \\
(0.72)\end{array}$ & $\begin{array}{l}0.000 \\
(0.01)\end{array}$ & $\begin{array}{l}-0.028 \\
(0.78)\end{array}$ \\
\hline Coal price & $\begin{array}{l}0.109 \\
(1.72)\end{array}$ & $\begin{array}{l}0.071 \\
(0.94)\end{array}$ & $\begin{array}{l}0.150 \\
(1.70)\end{array}$ & $\begin{array}{l}0.099 \\
(1.20)\end{array}$ & $\begin{array}{l}0.183 \\
(2.05)^{*}\end{array}$ \\
\hline Number of owners & $\begin{array}{l}-0.252 \\
(0.97)\end{array}$ & $\begin{array}{l}-0.369 \\
(1.52)\end{array}$ & $\begin{array}{l}-0.334 \\
(1.30)\end{array}$ & $\begin{array}{l}-0.342 \\
(1.62)\end{array}$ & $\begin{array}{l}-0.282 \\
(1.26)\end{array}$ \\
\hline Public ownership (dummy) & $\begin{array}{l}1.030 \\
(1.08)\end{array}$ & $\begin{array}{l}0.818 \\
(0.82)\end{array}$ & $\begin{array}{l}1.334 \\
(1.08)\end{array}$ & $\begin{array}{l}0.830 \\
(0.75)\end{array}$ & $\begin{array}{l}1.394 \\
(1.10)\end{array}$ \\
\hline Experience & $\begin{array}{l}0.060 \\
(1.96)^{*}\end{array}$ & $\begin{array}{l}0.045 \\
(1.95)\end{array}$ & $\begin{array}{l}0.055 \\
(2.64)^{* *}\end{array}$ & $\begin{array}{l}0.066 \\
(2.62)^{* *}\end{array}$ & $\begin{array}{l}0.083 \\
(3.99)^{* * *}\end{array}$ \\
\hline Fraction of nuclear energy generated & $\begin{array}{l}-2.918 \\
(1.11)\end{array}$ & $\begin{array}{l}-0.805 \\
(0.32)\end{array}$ & $\begin{array}{l}-0.280 \\
(0.09)\end{array}$ & $\begin{array}{l}2.102 \\
(0.68)\end{array}$ & $\begin{array}{l}3.399 \\
(0.97)\end{array}$ \\
\hline Social movement pressure & $\begin{array}{l}-0.055 \\
(1.11)\end{array}$ & $\begin{array}{l}-0.102 \\
(1.55)\end{array}$ & $\begin{array}{l}-0.136 \\
(1.87)\end{array}$ & $\begin{array}{l}-0.155 \\
(1.96)\end{array}$ & $\begin{array}{l}-0.234 \\
(2.67)^{* *}\end{array}$ \\
\hline Stigma intensity (orthogonalized) & & $\begin{array}{l}1.913 \\
(4.20)^{* * *}\end{array}$ & $\begin{array}{l}2.417 \\
(4.08)^{* * *}\end{array}$ & $\begin{array}{l}2.096 \\
(4.28)^{* * *}\end{array}$ & $\begin{array}{l}2.929 \\
(4.10)^{* * *}\end{array}$ \\
\hline Media exposure (orthogonalized) & & $\begin{array}{l}-0.669 \\
(0.64)\end{array}$ & $\begin{array}{l}-1.952 \\
(1.95)\end{array}$ & $\begin{array}{l}-0.767 \\
(0.67)\end{array}$ & $\begin{array}{l}-2.447 \\
(1.96)\end{array}$ \\
\hline Stigma Intensity X Media Exposure & & & $\begin{array}{l}-2.006 \\
(3.43)^{* * *}\end{array}$ & & $\begin{array}{l}-2.302 \\
(3.43)^{* * *}\end{array}$ \\
\hline Extent of membership & & & & $\begin{array}{r}-11.119 \\
(2.06)^{*}\end{array}$ & $\begin{array}{r}-15.796 \\
(2.94)^{* *}\end{array}$ \\
\hline Constant & $\begin{array}{l}5.424 \\
(0.67)\end{array}$ & $\begin{array}{l}9.247 \\
(1.25)\end{array}$ & $\begin{array}{l}7.584 \\
(0.77)\end{array}$ & $\begin{array}{c}10.774 \\
(1.34)\end{array}$ & $\begin{array}{c}13.658 \\
(1.47)\end{array}$ \\
\hline Pseudo-R ${ }^{2}$ & 0.58 & 0.65 & 0.70 & 0.68 & 0.74 \\
\hline$N$ & 214 & 214 & 214 & 214 & 214 \\
\hline
\end{tabular}




$$
* p<0.05 ; * * p<0.01 ; * * * p<0.001
$$

Table 4. Alternative model specifications with probit regression, LPM, and logit with SE clustered at the plant level.

\begin{tabular}{|c|c|c|c|}
\hline DV: unit cancellation & $\begin{array}{l}\text { Model } 6 \\
\text { (Probit) }\end{array}$ & $\begin{array}{c}\text { Model } 7 \\
\text { (LPM) }\end{array}$ & $\begin{array}{c}\text { Model } 8 \\
\text { (Logit with } \\
\text { plant-clustered } \\
\text { SE) }\end{array}$ \\
\hline Duration of project & $\begin{array}{l}-0.748 \\
(4.76)^{* * *}\end{array}$ & $\begin{array}{c}-0.085 \\
(9.88)^{* * *}\end{array}$ & $\begin{array}{l}-1.419 \\
(3.91)^{* * *}\end{array}$ \\
\hline Unit power (MW) & $\begin{array}{c}-0.004 \\
(2.21)^{*}\end{array}$ & $\begin{array}{l}-0.000 \\
(0.07)\end{array}$ & $\begin{array}{l}-0.007 \\
(1.86)\end{array}$ \\
\hline Unit type: BWR & $\begin{array}{l}1.672 \\
(3.09)^{* *}\end{array}$ & $\begin{array}{l}0.104 \\
(2.16)^{*}\end{array}$ & $\begin{array}{l}3.219 \\
(2.72)^{* *}\end{array}$ \\
\hline Unit type: experimental & $\begin{array}{l}-0.193 \\
(0.26)\end{array}$ & $\begin{array}{l}0.077 \\
(1.22)\end{array}$ & $\begin{array}{l}-0.216 \\
(0.12)\end{array}$ \\
\hline Three Mile Island (dummy) & $\begin{array}{l}7.075 \\
(3.32)^{* * *}\end{array}$ & $\begin{array}{l}0.468 \\
(2.94)^{* *}\end{array}$ & $\begin{array}{c}13.805 \\
(2.87)^{* *}\end{array}$ \\
\hline Units under construction, same plant (dummy) & $\begin{array}{l}0.972 \\
(1.74)\end{array}$ & $\begin{array}{l}0.056 \\
(0.83)\end{array}$ & $\begin{array}{l}1.786 \\
(1.55)\end{array}$ \\
\hline Units planned, same plant (dummy) & $\begin{array}{l}4.786 \\
(5.25)^{* * *}\end{array}$ & $\begin{array}{c}0.530 \\
(5.52)^{* * *}\end{array}$ & $\begin{array}{l}8.691 \\
(3.94)^{* * *}\end{array}$ \\
\hline Units under construction, same utility (dummy) & $\begin{array}{l}-0.585 \\
(1.07)\end{array}$ & $\begin{array}{l}0.016 \\
(0.22)\end{array}$ & $\begin{array}{l}-1.025 \\
(1.00)\end{array}$ \\
\hline Units planned, same utility (dummy) & $\begin{array}{c}-1.512 \\
(2.91)^{* *}\end{array}$ & $\begin{array}{c}-0.263 \\
(3.33)^{* *}\end{array}$ & $\begin{array}{c}-2.548 \\
(2.35)^{*}\end{array}$ \\
\hline Units under construction, same state (dummy) & $\begin{array}{l}0.099 \\
(0.13)\end{array}$ & $\begin{array}{l}0.032 \\
(0.37)\end{array}$ & $\begin{array}{l}-0.127 \\
(0.08)\end{array}$ \\
\hline Units planned, same state (dummy) & $\begin{array}{l}0.185 \\
(0.35)\end{array}$ & $\begin{array}{l}-0.009 \\
(0.12)\end{array}$ & $\begin{array}{l}0.251 \\
(0.19)\end{array}$ \\
\hline Operational units, same state (dummy) & $\begin{array}{l}0.498 \\
(1.22)\end{array}$ & $\begin{array}{l}0.057 \\
(1.04)\end{array}$ & $\begin{array}{l}1.000 \\
(1.19)\end{array}$ \\
\hline Utility size in MWh (logged) & $\begin{array}{c}-0.191 \\
(0.88)\end{array}$ & $\begin{array}{c}-0.016 \\
(0.80)\end{array}$ & $\begin{array}{c}-0.264 \\
(0.56)\end{array}$ \\
\hline Republican governor (dummy) & $\begin{array}{c}-0.116 \\
(0.40)\end{array}$ & $\begin{array}{l}-0.030 \\
(0.62)\end{array}$ & $\begin{array}{l}-0.174 \\
(0.26)\end{array}$ \\
\hline Oil price & $\begin{array}{c}-0.015 \\
(0.90)\end{array}$ & $\begin{array}{l}0.004 \\
(1.00)\end{array}$ & $\begin{array}{l}-0.030 \\
(0.84)\end{array}$ \\
\hline Coal price & $\begin{array}{l}0.085 \\
(1.94)\end{array}$ & $\begin{array}{l}0.001 \\
(0.21)\end{array}$ & $\begin{array}{l}0.169 \\
(1.68)\end{array}$ \\
\hline Number of owners & $\begin{array}{l}-0.212 \\
(1.84)\end{array}$ & $\begin{array}{c}-0.039 \\
(2.58)^{*}\end{array}$ & $\begin{array}{l}-0.330 \\
(1.45)\end{array}$ \\
\hline Public ownership (dummy) & $\begin{array}{l}0.676 \\
(1.28)\end{array}$ & $\begin{array}{l}0.094 \\
(1.15)\end{array}$ & $\begin{array}{l}1.380 \\
(1.15)\end{array}$ \\
\hline Experience & $\begin{array}{l}0.045 \\
(4.20)^{* * *}\end{array}$ & $\begin{array}{l}0.005 \\
(2.74)^{* *}\end{array}$ & $\begin{array}{l}0.079 \\
(3.86)^{* * *}\end{array}$ \\
\hline Fraction of nuclear energy generated & $\begin{array}{l}1.525 \\
(1.01)\end{array}$ & $\begin{array}{l}0.256 \\
(1.10)\end{array}$ & $\begin{array}{l}2.828 \\
(0.82)\end{array}$ \\
\hline Social movement pressure & $\begin{array}{l}-0.082 \\
(1.80)\end{array}$ & $\begin{array}{l}-0.003 \\
(0.42)\end{array}$ & $\begin{array}{c}-0.141 \\
(1.07)\end{array}$ \\
\hline Stigma intensity (orthogonalized) & 1.443 & 0.155 & 2.656 \\
\hline
\end{tabular}




\begin{tabular}{|c|c|c|c|}
\hline & $(4.86)^{* * *}$ & $(4.70)^{* * *}$ & $(4.33)^{* * *}$ \\
\hline Media exposure (orthogonalized) & $\begin{array}{l}-1.102 \\
(1.59)\end{array}$ & $\begin{array}{l}-0.088 \\
(1.06)\end{array}$ & $\begin{array}{l}-2.213 \\
(1.37)\end{array}$ \\
\hline Stigma Intensity X Media Exposure & $\begin{array}{l}-1.174 \\
(4.09)^{* * *}\end{array}$ & $\begin{array}{c}-0.113 \\
(2.21)^{*}\end{array}$ & $\begin{array}{l}-2.176 \\
(3.72)^{* * *}\end{array}$ \\
\hline Extent of membership & $\begin{array}{l}-7.624 \\
(3.56)^{* * * *}\end{array}$ & $\begin{array}{c}-0.688 \\
(2.87)^{* *}\end{array}$ & $\begin{array}{c}-13.645 \\
(2.92)^{* *}\end{array}$ \\
\hline Constant & $\begin{array}{l}7.872 \\
(1.65)\end{array}$ & $\begin{array}{c}1.118 \\
(2.17)^{*}\end{array}$ & $\begin{array}{c}12.518 \\
(1.36)\end{array}$ \\
\hline$N$ & 214 & 214 & 214 \\
\hline
\end{tabular}

$* p<0.05 ; * * p<0.01 ; * * * p<0.001$

Table 5. Alternative LPM specifications with state fixed effects, utility fixed effects and robust standard errors

\begin{tabular}{|c|c|c|}
\hline DV: unit cancellation & Model 9 & Model 10 \\
\hline Duration of project & $\begin{array}{c}-0.099 \\
(8.33)^{* * *}\end{array}$ & $\begin{array}{c}-0.099 \\
(7.54)^{* * *}\end{array}$ \\
\hline Unit power (MW) & $\begin{array}{l}-0.000 \\
(0.51)\end{array}$ & $\begin{array}{l}0.000 \\
(1.28)\end{array}$ \\
\hline Unit type: BWR & $\begin{array}{l}0.186 \\
(2.87)^{* *}\end{array}$ & $\begin{array}{c}0.180 \\
(2.66)^{* *}\end{array}$ \\
\hline Unit type: experimental & $\begin{array}{l}0.021 \\
(0.15)\end{array}$ & $\begin{array}{l}0.103 \\
(0.70)\end{array}$ \\
\hline Three Mile Island (dummy) & $\begin{array}{l}0.413 \\
(2.11)^{*}\end{array}$ & $\begin{array}{l}0.809 \\
(4.01)^{* * *}\end{array}$ \\
\hline Units under construction, same plant (dummy) & $\begin{array}{l}0.051 \\
(0.66)\end{array}$ & $\begin{array}{l}0.109 \\
(1.12)\end{array}$ \\
\hline Units planned, same plant (dummy) & $\begin{array}{l}0.424 \\
(3.73)^{* * *}\end{array}$ & $\begin{array}{c}0.393 \\
(3.17)^{* *}\end{array}$ \\
\hline Units under construction, same utility (dummy) & $\begin{array}{l}0.023 \\
(0.24)\end{array}$ & $\begin{array}{l}-0.033 \\
(0.23)\end{array}$ \\
\hline Units planned, same utility (dummy) & $\begin{array}{c}-0.272 \\
(2.71)^{* *}\end{array}$ & $\begin{array}{l}-0.149 \\
(1.29)\end{array}$ \\
\hline Units under construction, same state (dummy) & $\begin{array}{l}0.046 \\
(0.37)\end{array}$ & $\begin{array}{l}0.154 \\
(1.07)\end{array}$ \\
\hline Units planned, same state (dummy) & $\begin{array}{l}0.002 \\
(0.02)\end{array}$ & $\begin{array}{c}-0.077 \\
(0.77)\end{array}$ \\
\hline Operational units, same state (dummy) & $\begin{array}{l}0.193 \\
(2.38)^{*}\end{array}$ & $\begin{array}{l}0.145 \\
(1.63)\end{array}$ \\
\hline Utility size in MWh (logged) & $\begin{array}{l}-0.053 \\
(1.25)\end{array}$ & $\begin{array}{l}0.087 \\
(0.47)\end{array}$ \\
\hline Republican governor (dummy) & $\begin{array}{l}-0.104 \\
(1.34)\end{array}$ & $\begin{array}{l}-0.172 \\
(1.88)\end{array}$ \\
\hline Oil price & $\begin{array}{l}0.001 \\
(0.30)\end{array}$ & $\begin{array}{l}-0.002 \\
(0.36)\end{array}$ \\
\hline Coal price & $\begin{array}{l}0.001 \\
(0.11)\end{array}$ & $\begin{array}{l}0.007 \\
(0.97)\end{array}$ \\
\hline Number of owners & $\begin{array}{l}-0.064 \\
(2.60)^{*}\end{array}$ & $\begin{array}{l}-0.059 \\
(1.96)\end{array}$ \\
\hline Public ownership (dummy) & $\begin{array}{l}0.171 \\
(1.38)\end{array}$ & $\begin{array}{l}0.765 \\
(0.83)\end{array}$ \\
\hline Experience & $\begin{array}{l}0.008 \\
(3.32)^{* *}\end{array}$ & $\begin{array}{l}0.006 \\
(1.97)\end{array}$ \\
\hline Fraction of nuclear energy generated & $\begin{array}{l}0.232 \\
(0.93)\end{array}$ & $\begin{array}{l}0.397 \\
(1.10)\end{array}$ \\
\hline Social movement pressure & $\begin{array}{l}-0.001 \\
(0.13)\end{array}$ & $\begin{array}{l}-0.035 \\
(1.25)\end{array}$ \\
\hline Stigma intensity (orthogonalized) & $\begin{array}{l}0.189 \\
(5.54)^{* * *}\end{array}$ & $\begin{array}{l}0.160 \\
(3.78)^{* * *}\end{array}$ \\
\hline
\end{tabular}


Media exposure (orthogonalized)

$-0.049$

$-0.140$

Stigma Intensity X Media Exposure

(1.58)

(0.57)

$-0.144$

(2.49)*

$(2.38)^{*}$

Extent of membership

$-0.808 \quad-1.820$

$(2.79)^{* *} \quad(2.72)^{* *}$

State fixed effects

Yes

No

Utility fixed effects

No

Yes

Constant

2.335

$(2.19)^{*}$

$-1.824$

$R^{2}$

0.76

$(0.43)$

$\mathrm{N}$

214

0.84

214

${ }^{*} p<0.05 ; * * p<0.01 ; * * * p<0.001$ 